Review

\title{
Neuromodulators and Long-Term Synaptic Plasticity in Learning and Memory: A Steered-Glutamatergic Perspective
}

\author{
Amjad H. Bazzari * and H. Rheinallt Parri \\ School of Life and Health Sciences, Aston University, Birmingham B4 7ET, UK; parrihr@aston.ac.uk \\ * Correspondence: bazzaria@aston.ac.uk; Tel.: +44-(0)1212044186
}

Received: 7 October 2019; Accepted: 29 October 2019; Published: 31 October 2019

\begin{abstract}
The molecular pathways underlying the induction and maintenance of long-term synaptic plasticity have been extensively investigated revealing various mechanisms by which neurons control their synaptic strength. The dynamic nature of neuronal connections combined with plasticity-mediated long-lasting structural and functional alterations provide valuable insights into neuronal encoding processes as molecular substrates of not only learning and memory but potentially other sensory, motor and behavioural functions that reflect previous experience. However, one key element receiving little attention in the study of synaptic plasticity is the role of neuromodulators, which are known to orchestrate neuronal activity on brain-wide, network and synaptic scales. We aim to review current evidence on the mechanisms by which certain modulators, namely dopamine, acetylcholine, noradrenaline and serotonin, control synaptic plasticity induction through corresponding metabotropic receptors in a pathway-specific manner. Lastly, we propose that neuromodulators control plasticity outcomes through steering glutamatergic transmission, thereby gating its induction and maintenance.
\end{abstract}

Keywords: neuromodulators; synaptic plasticity; learning; memory; LTP; LTD; GPCR; astrocytes

\section{Introduction}

A huge emphasis has been put into discovering the molecular pathways that govern synaptic plasticity induction since it was first discovered [1], which markedly improved our understanding of the functional aspects of plasticity while introducing a surprisingly tremendous complexity due to numerous mechanisms involved despite sharing common "glutamatergic" mediators [2]. The considerable variation in the signalling pathways and induction requirements, mostly attributable to various methodological approaches across heterogeneous neuronal populations, itself is key to comprehend and properly stratify the diverse mechanisms by which specific neuronal subclasses control their synaptic strength and structure in association with learning, memory, sensory and motor functions [3,4]. However, at least in relation to long-term synaptic plasticity, the focus has been directed predominantly towards glutamatergic transmission, particularly the roles of N-methyl D-aspartate receptors (NMDARs) and calcium/calmodulin-dependent protein kinase II (CAMKII). Nonetheless, an extensive number of studies show critical roles for other neurotransmitters and modulators in long-term potentiation (LTP) and depression (LTD) through corresponding G-protein coupled receptors (GPCRs). In this review, we explore current evidence on the roles of neuromodulators as key effectors in the induction and maintenance of long-term synaptic plasticity and associated GPCRs involvement in the modulation and steering of glutamatergic transmission focusing on plasticity induction, which could facilitate future development of models determining the mechanisms that underlie certain cognitive, behavioural, learning and memory subtypes. 


\section{Metabotropic Pathways Are Necessary for Long-Term Synaptic Plasticity}

Long-term synaptic plasticity (i.e., LTP and LTD) can be generally classified either based on the loci of expression into presynaptic and postsynaptic forms or based on the molecular mediators into two broad categories, NMDAR-dependent and NMDAR-independent forms, both of which have been reported in different brain regions. It is thought that the "early" phase of LTP (e-LTP) mediates short-term "labile" memories that still require maintenance and the late phase for long-term storage [5-7]. Despite previous evidence in relation to NMDAR-dependent LTP showing key roles for CAMKII not only in the induction but also the maintenance of LTP [8-10], other studies show the opposite and it is proposed that the use of structural CAMKII inhibitors is difficult to interpret as they might affect baseline transmission [11-14]. However, it is well-known that long-term storage of plasticity-induced memories requires in the vast majority of cases gene expression, which is often referred to as the protein-synthesis phase of plasticity that is necessary for long but not short-term memory formation [15-19]. Accordingly - at least at specific synapses-the activation of certain GPCRs during plasticity induction is found to trigger the gene-expression and/or translation of messenger ribonucleic acid (mRNA) of proteins implicated, either functionally or structurally, in plasticity regulation, maintenance and memory consolidation such as brain-derived neurotrophic factor (BDNF), activity-regulated cytoskeleton-associated protein (Arc), fragile-x mental retardation protein (FMRP) and others [20-22].

It was previously shown that NMDAR-dependent LTP involves local protein synthesis, which precedes gene expression, or de novo protein production; however, various studies report that it is induced via activation of BDNF, dopamine and metabotropic glutamate receptors (mGluRs) [23]. In addition, local protein synthesis is also observed in NMDAR-independent forms of both LTP and LTD; for instance, through BDNF signalling and mGluRs, respectively [24,25]. Therefore, NMDAR-mediated activation of CAMKII auto-phosphorylation does not fully and solely explain both LTP induction and maintenance. However, recent evidence shows ion flux-independent metabotropic roles of NMDARs particularly in LTD, as some studies report that use-dependent blockade of NMDAR ion channel using dizocilpine (MK-801) is found to block LTP but not LTD in contrast to competitive antagonism using D-AP5 which blocks both [26]. With regards to NMDAR-independent plasticity in which GPCRs, most commonly mGluRs, have primary functions it might be argued that one exception is the voltage-gated calcium channel (VGCC)-dependent long-term plasticity in which VGCCs can induce NMDAR-independent plasticity and may be sufficient for induction [27-29]. However, VGCC-dependent LTP and LTD are also found to depend on either mGluRs (e.g., hippocampus and cerebellum) or both mGlu and NMDA receptors (insular cortex) [30-32]. Despite that different induction protocols, tissue preparations and experimental conditions can lead to varying results that should not be directly compared, experimental findings show that some plasticity mechanisms are shared by various neuronal populations and that the same synaptic population can exhibit different mechanisms for plasticity induction — with distinct expression mediators—-that could have independent functional outcomes.

Another mechanism by which GPCRs mediate both early and late phases of plasticity is through the activation of protein kinases, which can mediate the expression, trafficking and synaptic insertion of NMDA and/or AMPA ( $\alpha$-amino-3-hydroxy-5-methyl-4-isoxazolepropionic acid) receptors through downstream signalling, such as protein kinase A (PKA), PKC, PKMzeta, mammalian target of rapamycin (mTOR), phosphoinositide 3-kinase (PI3K) and mitogen-activated protein kinases (MAPK) all of which have been shown to be involved, either differentially or synergistically, in plasticity induction and/or maintenance [33-37]. In addition, with regards to the critical roles of astrocytes, GPCR activation and subsequent induction of astrocytic calcium signalling is found to trigger gliotransmitter release that can subsequently induce multiple forms of long-term plasticity either directly through both preand postsynaptic mechanisms or indirectly via altering neurotransmission to augment or prevent plasticity induction $[38,39]$. Another possible mechanism for GPCRs in synaptic plasticity is based on intracellular calcium mobilisation during induction as seen with mGluRs in cerebellar LTD [40]. 
Lastly, evidence shows G-protein-specific effects in plasticity outcome modulation; for instance, the activation of hippocampal (CA1) mGluR5 lowers the threshold for (i.e., promotes) LTD, while group II mGluRs prime NMDAR activation and facilitate LTP. On the other hand, mGluR3 blockade in the dentate gyrus impairs post-synaptic LTD while its activation modulates LTD presynaptically and impairs LTP; similarly, blocking group III mGluRs impairs LTD and long-term spatial memory but not LTP in CA1 neurons [41-44]. Additionally, mGluR activation is found to control the polarity of plasticity; for instance, in acute spinal slices of substantia gelatinosa, blocking mGluRs switches spike timing-dependent plasticity (STDP) following a pairing stimulation protocol from LTP to LTD, while, in hippocampal slices, the activation of mGluRs switches chemical LTD (cLTD) induced by brief application of NMDA into sustained LTP $[45,46]$.

\section{Neuromodulators in Synchronisation and Synaptic Plasticity}

Accumulating evidence illustrates critical plasticity roles for GPCRs, particularly mGluRs, through differential signalling pathways, and shows the involvement of other transmitters and modulators as key participants in synaptic plasticity and memory. It is evidently supported that long-term synaptic plasticity is the molecular mechanism of learning and memory as shown by evidence addressing the assessment criteria of the synaptic plasticity and memory (SPM) hypothesis [47]. Furthermore, since at its core long-term plasticity is a neuronal encoding mechanism, it is plausible to assume its involvement in the control of behaviour which is induced by previous experience. Indeed, evidence shows a strong correlation between synaptic plasticity and experience-dependent (i.e., motor and sensory) learning $[48,49]$. In addition, synaptic plasticity is found to be physiologically involved in stress, fear and emotional memory as well as pathologically in anxiety, major depressive disorder (MDD) and drug addiction [50-55]. It is well-known that the majority of aforementioned psychological, behavioural and learning subtypes rely heavily or at least partly on cholinergic, dopaminergic, serotonergic or adrenergic transmission [56].

The artificial-mostly in vitro-induction of long-term plasticity in acute slices or primary cultures requires the use of certain stimulation protocols suggested to mimic physiological patterns of network activity required for synaptic plasticity and memory, most commonly high-frequency, theta-burst and low-frequency stimulation (HFS, TBS and LFS, respectively) as well as pairing protocols [57]. It is strongly believed that brain rhythms represent oscillatory network activities responsible for multiple emotional, behavioural and memory functions. In addition, it is proposed that the clinical consequences of transcranial magnetic stimulation at certain frequencies are mediated by either short or long-lasting synaptic plasticity mechanisms [58,59]. Indeed, clinical and in vivo evidence shows frequency and network-based correlations between single-band/coupled brain oscillations and memory retention and/or retrieval; for instance, theta, theta/gamma, beta/gamma, theta/theta synchronous and alpha/gamma rhythms in different brain regions associate with spatial, associative, olfactory, fear and visual memories, respectively [60-64].

Neuromodulators provide fine regulation of network activities and are suggested to control frequency-dependent transmission [65]. Accordingly, evidence indicates that neuromodulators couple rhythmic activity and synaptic plasticity; for instance, hippocampal muscarinic $\mathrm{M}_{1}$ receptors are critical for theta-oscillations, LTP induction and spatial memory performance [66]. Moreover, increased expression of serotonin reuptake transporter blocks theta-oscillations in the amygdala and impairs fear learning while its deficiency causes delayed extinction learning and increased amygdala-prefrontal cortex (PFC) theta-synchronisation [67,68]. Furthermore, noradrenaline release following direct stimulation of locus coeruleus is reported to induce narrow-theta $(7-9 \mathrm{~Hz})$ oscillations and LTP in the dentate gyrus while in hippocampal CA1 region it results in transient theta suppression and LTD facilitation through $\beta$ adrenergic receptors $[69,70]$. Additionally, selective activation of dopamine $D_{4}$ receptor-which is associated with attention and working memory-induces gamma oscillations in the hippocampus though parvalbumin-positive interneurons; in contrast, $\mathrm{D}_{3}$ activation inhibits gamma oscillations and certain memory functions, whereas blocking $D_{1 / 5}$ receptors during memory-encoding 
impairs long-but not short-term retention [71-73]. On the other hand, low-frequency (slow-wave) delta oscillations are mostly observed during non-rapid eye movement (NREM) sleep. Slow-wave oscillations are hypothesised to downscale synaptic strength of synapses potentiated during wakefulness that would otherwise become saturated [74]. Little is known about the roles of modulators in slow-wave oscillations; however, the oscillations are found to be partly regulated by astrocytic adenosine-mediated inhibition through $\mathrm{A}_{1}$ receptors; additionally, blocking activity-driven BDNF expression reduces both NREM slow-wave oscillations and synchronous PFC-hippocampal theta oscillations during extinction learning $[75,76]$. Lastly, GPCR-induced expression of certain immediate early genes, namely c-Fos and fos B genes, is found to regulate slow wave sleep and delta oscillations [77].

The above findings provide direct evidence for the essential involvement of neuromodulators in both brain oscillations and memory processes. Despite extensive efforts to unravel the association between rhythmic brain activity and various behavioural and cognitive functions, the specific roles of neuromodulators remain incompletely understood. Additionally, network activity regulation is most likely resultant from balanced effects of multiple transmitters and modulators that vary between different brain states. Lastly, the metabotropic pathways by which neuromodulators control long-term synaptic plasticity, summarised in Figure 1 below, are shared by various neuromodulators, hence suggesting activity/behaviour-dependent and pathway-specific mechanisms. Therefore, the roles of neuromodulators in synaptic plasticity need to be investigated in relation to specific innervation pathways as well as associated learning subtypes through characterising their direct (i.e., synaptic) involvement in glutamatergic steering and plasticity induction, as discussed below.

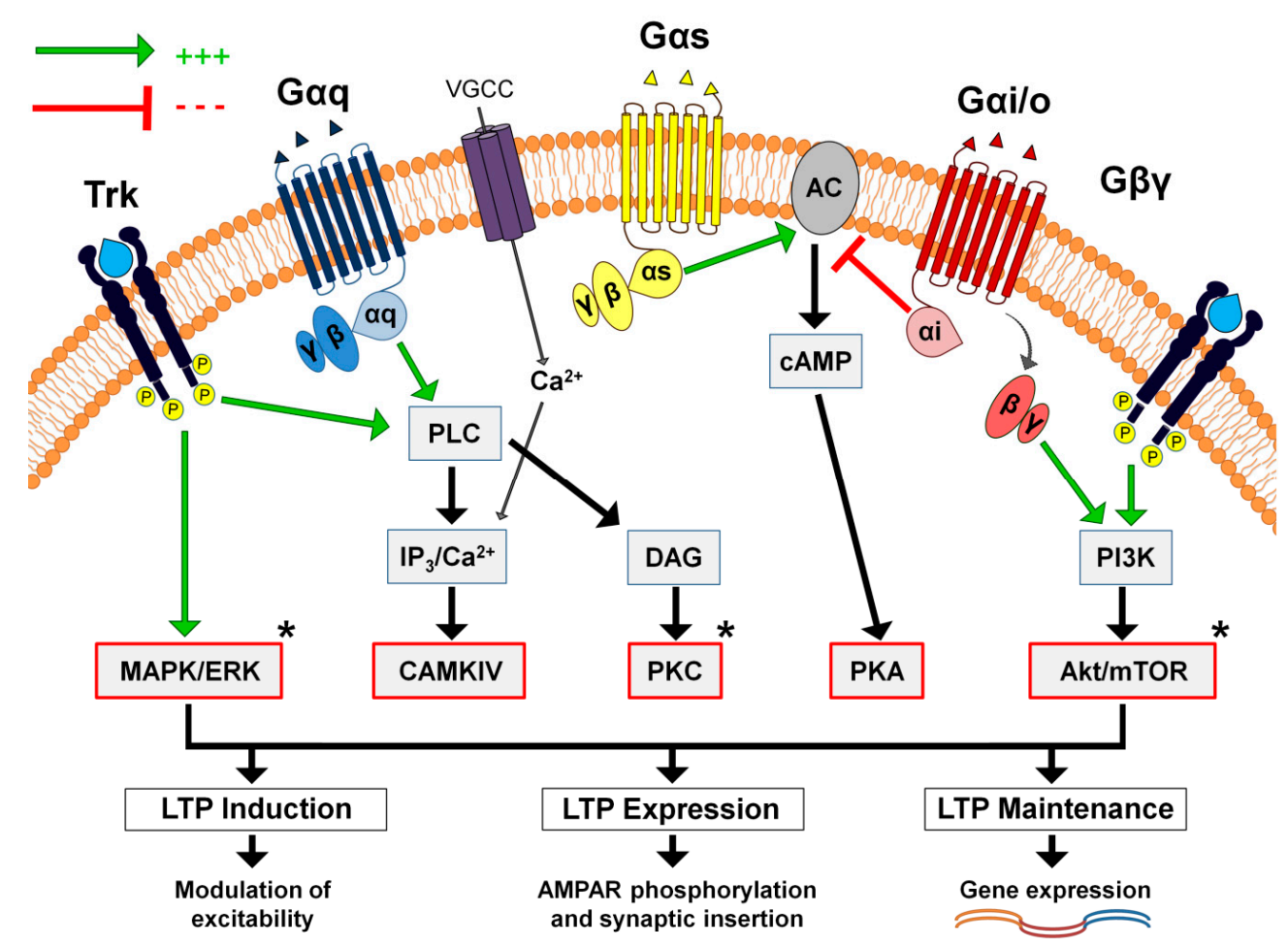

Figure 1. Schematic representation of the main metabotropic signalling pathways by which neuromodulators control long-term potentiation (LTP). Neuromodulators activate various protein kinases that can: Firstly, modulate neuronal excitability through controlling ion-channel conductance (e.g., NMDAR and VGCC) leading to the facilitation or direct induction of LTP. Secondly, protein kinases (e.g., PKA, MAPK and PKC) can initiate the expression, trafficking, phosphorylation and/or synaptic insertion of AMPA receptors leading to LTP expression. Lastly, protein kinases trigger the gene expression of proteins necessary for LTP maintenance. * It is also implicated in long-term depression (LTD), mostly through AMPA receptor internalisation. 


\section{Transmission System-Based GPCR Modulation of Plasticity}

\subsection{Dopaminergic Transmission}

Dopamine is the most-extensively studied neuromodulator in relation to synaptic plasticity due to its crucial roles in emotion and motor control in addition to its non-fully characterised but still critical involvement in cognition [78]. Despite subtype-specific polymorphisms, dopamine receptors are classified into two main classes, namely D1 and D2 receptors, also known as $\mathrm{D}_{1}$-like and $\mathrm{D}_{2}$-like receptors (subscript denotes receptor subtypes), respectively, which are widely but differentially expressed across the brain. The former (D1) comprises $D_{1}$ and $D_{5}$ receptor subtypes while the latter (D2) comprises $\mathrm{D}_{2-4}$ subtypes [79]. D1 receptors are coupled to Gs-protein, the activation of which stimulates adenylyl cyclase and subsequent cAMP (cyclic-adenosine monophosphate) production and PKA activation, while D2 receptors are coupled to Gi-protein and produce the opposite effect leading to reduced cAMP production. However, dopamine receptors have been shown to stimulate or inhibit other signalling pathways and intracellular effectors including $\mathrm{Ca}^{2+}$ channels, $\mathrm{K}^{+}$channels, $\mathrm{Na}^{+} / \mathrm{H}^{+}$ exchanger and $\mathrm{Na}^{+} / \mathrm{K}^{+}$ATPase pump in addition to critical roles in the induction and regulation of gene expression [80].

Dopaminergic pathways have been identified for decades; however, the clinical aspects, newly-identified inputs and projections and the concept of co-transmission represent more recent insights into dopamine signalling [81,82]. Midbrain dopaminergic neurons in the ventral tegmental area (VTA) and substantia nigra pars compacta (SNc) represent the two predominant sources of brain dopamine as a modulator of neurotransmission, that project to distinct brain regions [83]. More recent evidence shows that VTA and SNc exhibit differential connectivity covering the majority of brain regions. In addition, direct electrical and optogenetic stimulation of VTA dopamine release causes brain-wide network activity modulation even in regions receiving minimal to no VTA innervation [84,85]. However, in relation to long-term synaptic plasticity and associated learning and memory, the greatest body of evidence exists for mesocortical, nigrostriatal and mesolimbic pathways.

\subsubsection{Mesocortical Pathway}

Mesocortical projections from the VTA extend to the PFC and other cortical regions, particularly the primary motor cortex (M1-cortex). The roles of PFC dopamine in learning and memory are well-documented in relation to context encoding, spatial working memory, and emotional and associative learning mostly through phasic release [86]. Functional coupling between the PFC and VTA is shown to be mediated through phasic bidirectional control over sub-second timescales, which is found in computational models to be important for mediating and determining the maintenance and magnitude of long-term plasticity, respectively [87,88]. In addition, dopaminergic control of PFC activity is suggested to regulate the thresholds for LTP and LTD [89].

Evidence shows critical roles for dopamine in LTP and LTD of PFC neurons as $\mathrm{D}_{1}$ receptor is found essential for the maintenance but not induction of LTP while its agonist activation facilitates LTD induction through transforming transient LFS-induced depression into sustained LTD [90]. Additionally, dopamine is also reported to be essential for NMDAR-dependent LTP induction in vivo at hippocampal-PFC synapses through a D1- and PKA-dependent mechanism [91]. Moreover, direct VTA stimulation shows frequency-dependent modulation of plasticity and synaptic transmission at hippocampal-PFC synapses, highlighting the importance of mesocortical dopaminergic transmission in the induction of PFC long-term plasticity [92]. In vitro evidence shows that dopamine can facilitate either LTP or LTD at PFC Layers I/II-V synapses, in which brief dopamine application induces LTD and facilitates tetanic stimulation-induced LTD as well. On the other hand, when dopamine application precedes tetanic stimulation, it facilitates NMDAR-dependent LTP, suggesting an activity-dependent role of "background" dopamine, which reflects concurrent synaptic activation and NMDAR priming, in determining the polarity of plasticity [93,94]. Additional evidence for the critical involvement of dopaminergic transmission in long-term plasticity comes from novel forms of 
associativity; as dopamine-facilitated LTD following tetanisation is found to depend on simultaneous mGluR activation and synergistic activation of MAPK, cooperative activation of D1 and D2 receptors additionally allows extended timing-dependent LTP ( $\mathrm{t}$-LTP) through neuronal excitation and inhibition of GABAergic transmission, respectively $[95,96]$.

Most established evidence for PFC dopamine shows key roles in working memory and consolidation especially at hippocampal-PFC synapses as opposed to mostly-glutamatergic induction of long-term plasticity [97]. However, recent studies unveiled various mechanisms by which dopamine receptors modulate glutamatergic transmission to augment or depress PFC plasticity induction; for instance, D2 receptor activation depresses NMDAR transmission and disrupts synaptic function at hippocampal-PFC synapses, whereas at Layer V neurons D1 activation strengthens and depresses NMDAR-mediated and non-NMDAR-mediated excitatory currents, respectively, while decreasing neurotransmitter release following moderate-frequency $(20 \mathrm{~Hz})$ stimulation [98,99]. Moreover, dopamine receptors can directly affect NMDA and AMPA receptor expression, as D1 activation induces NR1/NR2B-containing NMDAR expression and trafficking in PFC neuronal cultures through a tyrosine kinase-mediated PKA-independent mechanism; moreover, D1 activation is found to induce PKA-dependent expression of surface GluA1 (formerly known as GluR1) subunit-containing AMPARs, which is suggested to be an LTP-facilitating mechanism, while D2 activation decreases synaptic expression of AMPARs in primary PFC cultures [100,101]. Interestingly, D1 receptors co-localise with NMDARs in PFC pyramidal neurons and D1 activation is found to potentiate NMDAR-mediated calcium influx through a PKA-mediated mechanism [102]. Furthermore, the activation of $\mathrm{D}_{4}$ receptor subtype on PFC GABAergic interneurons supresses their glutamatergic transmission through regulating calcineurin-dependent AMPAR trafficking; accordingly, $\mathrm{D}_{4}$-selective activation results in decreased neuronal and interneuronal (following a transient increase) spontaneous action potential frequency in contrast to dopamine itself, which depresses and increases neuronal and interneuronal firing, respectively $[103,104]$.

The critical involvement of dopamine in various functions of the PFC including executive function, attention and learning are indirectly supported by pathology and drug-induced effects on PFC plasticity; for instance, D2 receptor overactivation is found to induce LTD and subsequent long-lasting suppression of NMDAR transmission of hippocampal-PFC synapses as a suggested mechanism of schizophrenia-associated cognitive deficits [98]. On the other hand, low-dose amphetamine induces cAMP-PKA mediated LTP through D1, but not D2, and adrenergic receptors. However, higher doses impair potentiation through both D1 and D2 receptors by activating protein-phosphatase 1 (PP1), similar to the observed effects of inhibited dopamine reuptake, which impaired D1/D2-dependent MAPK (ERK1/2)-signalling-mediated LTD through D1 overactivation that was rescued by positive allosteric-modulation of mGluR5 [105,106]. Lastly, D1-induced PKA/mTOR signalling-dependent LTP is shown to underlie the antidepressant mechanism of the D1 agonist and $D_{2 / 3}$ antagonist levo-stepholidine in the medial PFC [107]. The aforementioned findings show distinct rather than directly opposite effects of $\mathrm{D}_{1}$ - and $\mathrm{D}_{2}$-like receptors and indicate that PFC dopamine is critically involved not only in the maintenance but also the gating, induction and expression of long-term synaptic plasticity and support key therapeutic potential in attention defects and psychiatric disorder-related mood and cognitive impairments.

The second main cortical region receiving VTA dopaminergic inputs is the M1-cortex in which dopamine is found essential in motor skill acquisition and associated long-term plasticity through D1 and D2 receptors [108]. Immunohistochemistry staining-based retrograde tracing provides direct evidence that VTA projections release dopamine in the M1-cortex that subsequently mediates gene expression and plasticity-based motor skill learning but not retrieval, which is mimicked through direct VTA stimulation and blocked by VTA lesioning that is rescued via direct levodopa injection [109]. Similar to the aforementioned results in the PFC, dopamine-mediated LTP is not necessarily PKA-dependent as LTP and motor learning are found to depend on D1 and D2 receptor modulation of phospholipase C (PLC) activation rather than PKA in the M1-cortex [110]. Dopamine also has direct modulatory 
effects on M1-cortex network activity, neuronal excitability, gene expression, synaptic transmission and LTP induction supporting its roles in the encoding, mapping and storage of skill memory [111]. It is found that D2 but not D1 receptor blockade reduces forelimb representation and elevates movement thresholds. In addition, dopamine denervation results in the loss of LTP, neuronal recruitment and synaptic reorganisations that are required for accurate and refined movement during motor learning $[112,113]$.

\subsubsection{Nigrostriatal Pathway}

SNc dopaminergic projections extend to the dorsal striatum (DS)—comprising the putamen and caudate nucleus - which receives excitatory glutamatergic inputs from the thalamus and cortex (i.e., corticostriatal pathway) and is suggested to be critically involved not only in movement, as a critical component of the basal ganglia system, but various other functions including cognitive, emotion and motivation-based decision making and learning [114]. The vast majority $(95 \%)$ of striatal neurons are GABAergic principal medium spiny neurons (MSNs) while the rest are cholinergic interneurons $(0.5 \%-1 \%)$ and distinct subtypes of GABAergic aspiny interneurons ( $3 \%-4 \%)$ [115]. A considerable body of evidence shows key roles for SNc in learning and memory in addition to associated dopamine release in the control of LTP and LTD of striatal MSNs. Early investigations showed that direct stimulation of SNc during learning impairs memory retention, followed by studies directly implicating $\mathrm{SNc}$ in spatial/relational learning independently from hippocampal function in rodents and a potential role in reinforcement learning in humans [116-119].

Multiple experimental models of Parkinson's disease (PD) have been developed, of which the most commonly studied models are based on direct lesioning or selective-toxicity induction of dopaminergic SNc neurons [120,121]. In PD models and patients, the disruption or loss of SNc dopamine is found to impair long-term plasticity in both M1-cortex and DS in which plasticity alterations are believed to mediate PD and L-DOPA associated motor impairments and dyskinesia, respectively [122,123]. The corticostriatal plasticity impairments are found to depend on the level of denervation in which minimal dopamine reductions which correspond to mild/early PD impair NMDAR-dependent LTP but not LTD in contrast to complete depletion, which impairs both [124]. Consistent with this, dopaminergic neuron transplantation in PD rat-model shows that improved motor symptoms are associated with synaptic plasticity restorations that are seen only within the region of the graft [125]. Furthermore, the inability of L-DOPA to rescue M1-cortex plasticity in naïve PD patients despite clinical improvements, while restoring M1-cortex LTP in non-dyskinetic but not dyskinetic patients in some studies in addition to direct evidence in mouse models associating unidirectional striatal plasticity of the direct and indirect pathways in PD symptoms and L-DOPA-induced dyskinesia provide clear evidence for the critical roles of corticostriatal plasticity in motor control and that pathway-selective effects of dopamine mediate plasticity-associated functional alterations under healthy/physiological conditions [126-128].

Various studies investigating the mechanisms underlying long-term plasticity at corticostriatal synapses show that LTP is readily induced via TBS and HFS, NMDAR-mediated and dependent on D1 receptor activation $[129,130]$. Furthermore, corticostriatal D1 activation is found essential for the induction of both LTP through a PKA-dependent mechanism and LTD through a PKG-dependent mechanism that are induced in functionally-distinct neuronal populations [131]. On the other hand, $t$-LTP induced via pairing stimulation requires endocannabinoids $(e C B)$ and presynaptic $\mathrm{D}_{2}$-like receptors in contrast to $t-L T D$ that requires $\mathrm{D}_{1}$-like receptors and $\mathrm{eCB}$ signalling at corticostriatal but not thalamostriatal synapses and is mostly expressed postsynaptically [132-134].

Despite the lack of structurally-defined subsets of corticostriatal MSNs, two main movement-control and possibly action-selection pathways arising from DS projections have been identified and are classified based on the connection with the basal ganglia "interface" into direct and indirect pathways, both of which being critically modulated by SNc dopamine afferents [135]. Direct-pathway MSNs primarily express $D_{1}$-like receptors while $D_{2}$-like receptors are primarily found 
on indirect-pathway MSNs, both of which are found to undergo LTP and LTD through different mechanisms as discussed, and are described in detail by Cerovic and colleagues in a recent review (2013) in which the authors propose models explaining the induction and expression of long-term plasticity at both pathways [136]. Interestingly, strain variations in the proportion of long and short splice variants of $D_{2}$ receptors result in differential responses to mesostriatal $D_{1 / 2}$ co-stimulation in relation to c-Fos expression and neurobehavioural plasticity, which is suggested to affect liabilities to certain psychopathologies [137].

Lastly, in relation to long-term synaptic plasticity, dopamine is found to control glutamatergic transmission in the DS through differential D1 and D2 receptor-mediated modulation of intrinsic neuronal excitability via multiple mechanisms through regulating $\mathrm{K}^{+}, \mathrm{Na}^{+}, \mathrm{VGCC}$, AMPAR and NMDAR channel currents during transmission that adjust dendritic excitability and subsequently plasticity induction in addition to regulating AMPAR surface expression and presynaptic neurotransmitter release $[138,139]$.

\subsubsection{Mesolimbic Pathway}

The second main VTA dopaminergic projection innervates the ventral striatum, particularly the nucleus accumbens (NAcc)—comprised of core and shell subregions involved in limbic and motor control-which has long been heavily implicated in various behaviours and cognitive functions such as reward, aversive learning, motivation, addiction, declarative learning and memory [140,141]. The NAcc receives glutamatergic excitatory inputs from five main brain structures or pathways: the PFC, hippocampus, amygdala, thalamus and VTA all of which are modulated by dopamine and proposed to mediate distinctive functions [142-145]. However, the functional differences between input pathways are not clear and show various interrelated roles; for instance, thalamic-NAcc inputs are found to mediate aversive memory and opiate withdrawal effects following chronic exposure-induced LTP, while amygdala but not PFC inputs facilitate reward seeking. On the other hand, hippocampal-NAcc inputs are found essential for spatial/reference memory and conditioned place preference LTP that is impaired following stress. In addition, PFC-NAcc inputs are potentiated following cocaine self-administration and believed to mediate seeking and withdrawal while VTA glutamatergic inputs on NAcc GABAergic interneurons are shown to drive aversion [146-151].

NAcc dopamine efflux is found critical in regulating activity-based selection of multiple inputs that either converge monosynaptically, as hippocampal and PFC inputs, or heterosynaptically; for instance, stimulating the hippocampal pathway causes D1-mediated potentiation and inhibits amygdala inputs through $\mathrm{D} 1$ and adenosine $\mathrm{A}_{1}$ receptors, whereas simultaneous pathway stimulation potentiates both [143,152]. In addition, it was found that direct amphetamine injection, during simultaneous place and cue conditioning, in the NAcc shell and core regions facilitate and impair hippocampal-dependent place conditioning respectively; similarly, blocking dopamine receptors in NAcc shell attenuated place conditioning in contrast to NAcc core dopamine blockade which facilitated and also impaired place and cue-conditioning, respectively [153]. Lastly, one plausible input-selection mechanism is based on lateral inhibition through GABAergic MSN transmission which is found to be attenuated by $\mathrm{D} 1$ receptor activation that is suggested to: eliminate competitive pathway interactions, cause a shift in input selection and amplify associated afferent signals [154]. Therefore, NAcc dopaminergic modulation of input signal gains could determine which pathways undergo plasticity changes based on behaviourally relevant stimuli.

The roles of NAcc dopamine in learning and behaviour are well-documented: for instance, in spatial memory consolidation through both D1 and D2 receptors, food-reinforced instrumental learning requiring coincident D1 and NMDAR activation, fear conditioning, reward learning through distinct but still cooperative effects of D1/D2 receptors and motivation, which is suggested to depend on neuronal-calcium sensor 1-mediated regulation of D2 receptors [155-159]. The neuronal composition of the NAcc is very similar to the DS consisting primarily of $D_{1}$ - and $D_{2}$-like receptor-expressing MSNs 
and, in addition to the aforementioned modulatory roles of dopamine, various studies report its direct roles in plasticity induction, particularly LTP at NAcc synapses.

The D1-mediated activation of PKA in NAcc neurons is found to induce the expression, phosphorylation and synaptic insertion of AMPARs in NAcc cultures; in addition to priming LTP, providing a narrow time-detection mechanism for potentiation and mediating both the induction and maintenance of aversive memory at D2-expressing MSNs [160-165]. Furthermore, the induction of LTP in the NAcc requires D1/mGluR5 coactivation in a concentration-dependent manner as elevated dopamine and/or glutamate levels are found to impair associated HFS-induced LTP [166]. On the other hand, little is known about the mechanisms by which dopamine regulates NAcc LTD. Nonetheless, plasticity-related functional and structural alterations in motivational drive and drug abuse provide key insights on NAcc dopamine signalling and possible therapeutic potential in the management of drug addiction and withdrawal $[167,168]$.

\subsubsection{Hippocampal Dopamine}

The hippocampus has a central role in the study of learning and memory mechanisms with regards to synaptic plasticity and has been the focus of extensive research for many decades with multiple pathway-specific and network-based models [169]. The roles of various neuromodulators were studied in relation to hippocampal plasticity including dopamine. The VTA has been previously considered as the main and only source of hippocampal dopaminergic transmission; however, dopamine is shown to be released from the axons of locus coeruleus adrenergic neurons as well, which are more-densely found in the dorsal hippocampus, particularly the dorsal CA1 and CA3 regions, in contrast to VTA projections that innervate ventral regions with only sparse dorsal presence [170]. The roles of dopamine in relation to hippocampal-dependent learning and memory are well-documented and dopamine is argued to promote more-motivational memories in relation to adaptive behaviour and hippocampal function [171].

Interestingly, it was previously proposed that dorsal and ventral regions of the hippocampus mediate distinctive memory subtypes (cognition and emotion-based memories respectively) [172]. More recent evidence suggests that dopaminergic modulation is source/region-dependent and that VTA-ventral and locus coeruleus-dorsal hippocampal inputs are proposed to control two types of novelty-related memories described as "common" and "distinct" novelties, respectively, with regards to the presence or lack of past experience [173]. Similarly, novel-environment exposure results in a brief period of reduced LTP induction threshold through a D1 receptor-mediated facilitation mechanism, suggesting a key role in the retention of unexpected information [174]. Environmental novelty is found to trigger locus coeruleus neuronal firing that subsequently mediates the enhancement of acquired novelty-related memories through dopaminergic D1 but not adrenergic receptors [175]. Dopamine is also found essential for functional coupling of network activities during learning and memory formation; for instance, between the hippocampus and amygdala during the acquisition of fear conditioning through D1 receptors and between the hippocampus and caudate nucleus for episodic memory, which shows positive interrelation with D2 receptor availability in both regions $[176,177]$.

In regards to the mechanisms by which dopamine modulates hippocampal long-term plasticity, most studies have focused on the CA1 region. In hippocampal neuronal cultures D1 receptor activation induces dendritic local protein synthesis, GluA1-subunit upregulation, AMPAR surface insertion and enhanced synaptic transmission [178]. Early evidence from acute hippocampal slices showed that D1 receptor activation during LTP induction is required for the late phase of CA1 LTP induced following stratum radiatum (i.e., Schaffer collaterals) tetanisation, as D1 antagonists applied during but not directly following induction impair the late phase, confirmed by a later study showing that D1 mediates the maintenance of HFS-induced Schaffer collateral-CA1 NMDAR-dependent LTP which requires CA1 protein synthesis and that direct D1 activation by itself can induce a slow-onset LTP $[179,180]$. Interestingly, it was found in a later study that the D1 agonist-mediated LTP requires NMDAR activation as well [181]. Accordingly, D1 receptor activation is found to partly contribute to 
the magnitude ( $20 \%-25 \%$ ) of early (up to 40 minutes) LTP, an effect mimicked by the adenylyl-cyclase activator forskolin, suggesting a PKA-mediated mechanism [182]. However, a more recent study investigating the slow-onset D1-induced LTP, in CA1 neurons, shows differential dose-dependent roles of MEK (MAPK/ERK pathway) and CAMKII enzymes as both were essential for LTP induction following weak/low-dose D1 activation, whereas with stronger dopaminergic D1 activation the role of CAMKII becomes partial and no longer a prerequisite for LTP induction in contrast to MEK1/2 role which remains necessary [183].

CA1 dopamine is found in vivo to facilitate not only late-phase LTP but also late LTD associated with object exploration through D1 receptors; similarly, D2 receptors are essential for the expression of both LTP and LTD as well, the latter of which is found necessary for spatial learning and dependent on presynaptic D2 receptors [184,185]. Interestingly, the D1 agonist SKF83959, which is reported to activate PLC, is found to induce and facilitate LFS-induced LTD, which was dependent on NMDAR, PLC, calcineurin and free cytosolic $\mathrm{Ca}^{2+}$, as the LTD facilitation was attenuated using a cell permeable $\mathrm{Ca}^{2+}$ chelator (BAPTA-AM) [186].

Lastly, subtype-selective effects of D2 receptors in plasticity are also reported; for instance, $\mathrm{D}_{3}$ activation significantly increases LTP while $\mathrm{D}_{4}$ receptor activation results in complete depotentiation (i.e., LTP reversal) in CA1 neurons and mediates the plasticity effects of neuregulin-1, which has been linked to schizophrenia $[187,188]$.

\subsection{Cholinergic Transmission in the Hippocampus}

The critical involvement of acetylcholine in learning and memory, particularly in relation to acquiring novel information, are well-documented through studying the effects of lesioning and pharmacological antagonism that show region and task-specific functions which are suggested to rely on acetylcholine-mediated afferent input enhancement, spiking persistence and modulation of inhibition [189]. Acetylcholine exerts its actions through two main classes of receptors: ionotropic nicotinic (nAchR) and metabotropic muscarinic (mAchR) acetylcholine receptors that include various subclasses. Nicotinic receptors are ligand-gated cation channels the permeability of which relies on the subunit composition; generally, most subtypes are permeable to $\mathrm{Na}^{+}$and $\mathrm{K}^{+}$while $\alpha 7-\mathrm{nAchR}$ shows rapid sensitisation and significant $\mathrm{Ca}^{2+}$ permeability [190]. In relation to synaptic plasticity, most evidence exists for $\alpha 7-n A c h R$, which has been shown to be heavily involved in Alzheimer's disease pathology in addition to cognition and memory processes [191,192]. On the other hand, five muscarinic receptor subtypes have been identified and are either coupled to $G q\left(M_{1}, M_{3}\right.$ and $M_{5}$ subtypes) or $\mathrm{Gi}\left(\mathrm{M}_{2}\right.$ and $\mathrm{M}_{4}$ subtypes) G-proteins and show differential distribution across multiple brain regions and synaptic loci of expression [193].

Three main populations or nuclei of cholinergic neurons have been identified; the medial septal nucleus, which is the main source of hippocampal acetylcholine, the basal nucleus of Meynert (NBM) which mostly innervates the cerebral cortex and the pedunculopontine tegmental nucleus, all of which are suggested to coordinate cognitive processes [194,195]. Moreover, cholinergic (i.e., acetylcholine releasing) interneurons are known contributors to synaptic plasticity in specific synaptic populations, particularly at corticostriatal synapses [196]. With regards to long-term synaptic plasticity, cholinergic pathways have not been characterised as well as dopamine; however, the most studied cholinergic system is the septohippocampal pathway-encompassing the hippocampal formation, the septum and their interconnections in addition to afferent and efferent pathways-which has been heavily implicated in memory-related processes including information encoding, retrieval and consolidation [197]. As previously mentioned, neuromodulators induce synchronous neuronal activity associated with synaptic plasticity as well as memory and of particular importance in relation to the hippocampus is the septal cholinergic transmission which is often described as the theta-rhythm generator, which is required for hippocampal LTP $[66,198]$. Moreover, evidence suggests intrinsic theta-generating capabilities of the hippocampus that, together with septum-originating rhythms, rely heavily on muscarinic receptors $[199,200]$. 
Muscarinic receptors are essential for various types of learning and memory functions; for instance, $\mathrm{M}_{1}$ receptor blockade impairs emotional and spatial memory as well as the retrieval of fear conditioning while blocking presynaptic $\mathrm{M}_{2}$ autoreceptor enhances acetylcholine release and subsequently improves spatial memory and cognitive performance in contrast to $\mathrm{M}_{2}$ knockout mice that exhibit impairments in working memory and acquisition but not reference memory or retention [201-206]. Evidence shows key memory roles for hippocampal $\mathrm{M}_{3}$ and $\mathrm{M}_{4}$ receptors, the latter of which is significantly reduced in Alzheimer's disease and its activation, and, in addition to $\mathrm{M}_{1}$ receptor, is proposed as a novel treatment approach in Alzheimer's disease [207-210]. Conversely, the molecular mechanisms by which muscarinic receptors modulate synaptic plasticity and cognitive functions are less understood; however, evidence shows critical modulatory roles on hippocampal network functions accomplished via coordinated muscarinic and nicotinic receptor activation [211]. Briefly, presynaptic muscarinic receptors (i.e., $\mathrm{M}_{2}$ and $\mathrm{M}_{4}$ ) regulate neurotransmitter release while postsynaptically expressed (i.e., somatic and dendritic) in addition to astrocytic and inhibitory interneuron receptors control their excitability, through multiple mechanisms, via precise spatiotemporal regulation arising from both phasic and tonic release which is supported by evidence showing that synergistic activation of multiple muscarinic receptor subtypes is essential for both memory acquisition and retrieval [212,213].

Various studies have directly investigated the roles of muscarinic receptors, particularly $\mathrm{M}_{1}$, in the induction and maintenance of long-term synaptic plasticity in the hippocampus and show timing and concentration-dependent effects. Early evidence shows that HFS-induced LTP at CA3-CA1 synapses can be enhanced by the activation of $\mathrm{M}_{1}$ receptors using low carbachol concentration or direct stimulation of acetylcholine release, and both effects were abolished in $\mathrm{M}_{1}$ but not $\mathrm{M}_{3}$ knockout mice despite that LTP was preserved. In contrast, high concentrations of carbachol resulted in short-lasting synaptic inhibition, which was impaired in $\mathrm{M}_{1}$ and $\mathrm{M}_{1} / \mathrm{M}_{3}$ knockout mice [214]. These results were confirmed in a later study in which $\mathrm{M}_{1}$ activation facilitated TBS-induced LTP through inhibiting postsynaptic small conductance $\mathrm{Ca}^{2+}$-activated $\mathrm{K}^{+}(\mathrm{SK})$ channels, thereby preventing their hyperpolarising effect leading to enhanced NMDAR channel opening/activation during TBS and subsequently LTP facilitation [215]. Moreover, direct agonist activation of $\mathrm{M}_{1}$ receptors significantly increases neuronal excitability, enhances spike-coupling and is found sufficient to induce robust NMDAR-dependent LTP that occludes, and therefore shares similar mechanisms with, stimulus/TBS-induced LTP at CA3-CA1 synapses [216]. Interestingly, the activation of not only surface but also intracellular $\mathrm{M}_{1}$ receptors enhances LTP, the latter of which is mediated through the phosphorylation of ERK1/2 [217]. It was found in vivo as well that the muscarinic $\mathrm{M}_{1}$ receptor is required for CA1 LTP induction and that acetylcholine preconditioning through stimulating septal release provides a narrow time-window of lowered LTP induction threshold that was prevented when atropine was applied [218]. Lastly, a special form of anti-Hebbian LTP induced at inhibitory CA1 interneurons that favour postsynaptic hyperpolarisation is found dependent on the co-activation of $\mathrm{M}_{1}$ and group I mGluR, which shows a new mechanism by which cholinergic inputs regulate network transmission as this form of potentiation results in a long-term increase of inhibition that is suggested to regulate input/pathway selection [219].

The $\mathrm{M}_{1}$ receptor is also involved in LTD induction; for instance, presynaptic (CA3) $M_{1}$ receptors are found essential, through a PKC-dependent mechanism, for the induction of mGluR CLTD [220]. In addition, LTD induced through direct agonist activation of $\mathrm{M}_{1}$ receptors in the hippocampus is shown to rely on different molecular mediators that lead to AMPAR endocytosis compared to mGluR-cLTD despite sharing the same G-protein subtype (i.e., $\mathrm{Gq}$ ); moreover, another form of $\mathrm{M}_{1}$-induced NMDAR-dependent LTD is found dependent on $\mathrm{IP}_{3}$-mediated intracellular $\mathrm{Ca}^{2+}$ release and is expressed via NMDAR internalisation [221,222]. On the other hand, the molecular mechanisms by which $\mathrm{M}_{2-5}$ muscarinic receptors modulate synaptic plasticity are less understood despite being critically involved in learning and memory as previously discussed; however, the different subtypes of muscarinic receptors exhibit different roles in plasticity modulation [223]. Ultimately, the substantial involvement of acetylcholine in cognitive processes and synaptic plasticity in addition to 
network function modulation, neuronal synchronisation and neurodegenerative disorders, particularly Alzheimer's disease, warrant further investigation.

\subsection{Adrenergic Transmission}

Noradrenaline (norepinephrine) in the brain has fundamental roles in various behaviours, namely: arousal, attention, motivation, stress and vigilance. In addition, emerging evidence supports its key roles in learning and memory [224]. Noradrenaline is exclusively released from a specific group of brainstem nuclei (A1-A7), predominantly locus coeruleus, that project and supply noradrenaline across various brain regions and of particular importance in relation to cognitive function are the PFC and the hippocampus [225]. Noradrenaline targets two main classes of receptors, namely $\alpha$ and $\beta$ adrenoceptors. The former comprises $\alpha_{1}$ and $\alpha_{2}$ receptors, which are coupled to Gq and Gi proteins, respectively, while the latter comprises $\beta_{1}, \beta_{2}$ and $\beta_{3}$ receptors, all of which are coupled to Gs protein while $\beta_{2 / 3}$ receptors are also coupled to $\mathrm{Gi}$.

In relation to learning and memory functions, noradrenaline release in the hippocampus, within a narrow time window of learning/acquisition, is found essential in memory formation and consolidation. In addition, the key modulatory roles of noradrenaline in emotional/stress, fear and spatial working memories are well-documented [226-230]. Accordingly, noradrenaline release from the locus coeruleus is proposed to control cognitive flexibility and orientation of attention as supported by evidence showing spatiotemporal association between noradrenaline release and different brain states through both brain-wide and region-specific activity modulation, especially in relation to hippocampal and cortical oscillations [231,232].

It has been recently found that dopamine is also released from locus coeruleus adrenergic neurons [170], which would require reinterpretation of earlier findings that investigated noradrenaline role in synaptic plasticity through locus coeruleus stimulation, or activity monitoring, without pharmacological confirmation of adrenoceptor involvement. Therefore, the molecular mechanisms by which noradrenaline regulates synaptic plasticity are reviewed based on adrenoceptor-selective effects. The strongest evidence in relation to synaptic plasticity exists for $\beta_{2}$ receptors; however, other adrenoceptors have been shown to not only be involved in synaptic plasticity and memory but also exhibit complex interactions requiring the combined effects of multiple receptor subtypes as will be discussed.

Early evidence showed that $\alpha_{1}$ receptor activation facilitates spatial learning despite not being an essential requirement for acquisition [233]. This was later confirmed using mutant mice expressing a continuously active form of $\alpha_{1 \mathrm{~A}}$ receptor subtype. These exhibited enhanced hippocampal LTP induction and cognitive performance, in contrast to $\alpha_{1 \mathrm{~A}}$ knockout mice which exhibited poor cognitive functions [234]. Interestingly, the simultaneous blockade of $\alpha_{1}$ - and $\beta$-type adrenoceptors is found to impair spatial avoidance learning; however, the antagonism of either receptor separately was unable to impair locomotion, which suggests an adrenoceptor interaction required for the regulation of navigation and learning [235]. Similarly, $\alpha_{1 \mathrm{~A}}$ and $\beta_{1}$ adrenoceptors provide bidirectional regulation of the magnitude of kainate-induced hippocampal gamma oscillations, which illustrates how noradrenaline can either promote or depress oscillations with possible relation to information processing in learning and memory [236]. In contrast, antagonising $\alpha_{1}$ receptors is found to facilitate LTP and fear conditioning in the amygdala through suppressing and promoting inhibitory and NMDAR currents, respectively. In addition, $\alpha_{1}$ antagonism is also shown to dose-dependently potentiate NMDA but not AMPA or kainate receptor currents in hippocampal CA1 neurons resulting in significant enhancement of spatial learning and memory $[237,238]$. These results show how noradrenaline, through $\alpha_{1}$ receptors, bidirectionally regulates synaptic plasticity and memory formation not only through regulating LTP induction/maintenance but also through direct LTD induction, as previously reported in the hippocampus that $\alpha_{1}$ receptor activation induces NMDAR-dependent LTD, which requires pre- and postsynaptic neuronal activity and is independent on the activation of $\mathrm{GABA}_{\mathrm{A}}$ receptor or other adrenoceptors [239]. 
$\alpha_{2}$ adrenoceptors mostly serve an inhibitory presynaptic autoreceptor role and their in vivo activation is reported to impair HFS-LTP induced at Schaffer collaterals CA3-CA1 synapses in a dose-dependent manner that was accompanied with decreased hippocampal overall neuronal glutamate content and increased paired-pulse facilitation ratio (i.e., reduced presynaptic glutamate release), which is suggested to be mediated through inhibiting HCN channels (i.e., hyperpolarisation-activated cyclic nucleotide-regulated channels) [240]. Interestingly, the activation of $\alpha_{2}$ receptors in the basolateral amygdala was shown in vivo to augment HFS-induced LTP at hippocampal-PFC synapses while its blockade impaired LTP induction; as opposed to the non-selective activation and blockade of $\beta$ receptors in the amygdala which reduced and enhanced LTP respectively at the same synapses [241].

$\beta$ adrenoceptors, particularly the $\beta_{2}$ subtype, have been more-heavily investigated in relation to synaptic plasticity induction and maintenance. In the hippocampus, a recent study shows that $\beta$ adrenoceptors selectively augment LTP in the ventral CA1 region, which shows higher adrenergic sensitivity compared to the dorsal region, leading to enhanced TBS-induced LTP magnitude and stability. In addition, the exogenous application of isoprenaline resulted in increased postsynaptic excitability, facilitated VGCC-mediated LTP and the induction of robust NMDAR-dependent LTP following subthreshold primed stimulation in the ventral CA1 in contrast to moderate burst response enhancement in dorsal CA1 region [242]. This is in accordance with more recent findings that the source of hippocampal dopamine is region-dependent as ventral regions are mostly VTA innervated while dorsal regions receive dopamine from locus coeruleus [173], suggesting distinct modulatory roles between hippocampal dopamine and noradrenaline. Additionally, the facilitated induction of hippocampal prefrontal path LTP, following weak electrical stimulation, through the application of methylphenidate which inhibits the reuptake of dopamine and noradrenaline is found to rely on both $\beta$ and, to a larger extent, D1 receptors leading to improved working memory [243]. Moreover, the combined activation of $\beta_{1}$ receptor and $\mathrm{M}_{1}$ muscarinic receptor using isoprenaline and carbachol, respectively, shows synergistic activation of mTOR, ERK and protein translation in hippocampal CA1 neurons leading to the transformation of stimulus-induced short-term potentiation into sustained LTP [244]. Despite some studies using exogenous agonist application, which may be argued to be an imperfect physiological representation, these results show novel forms of interactions hinting towards intracellular coincident detectors downstream of GPCR activation.

Multiple studies selectively investigated $\beta_{2}$ adrenoceptors which have been shown to play critical plasticity roles through various mechanisms; for instance, $\beta_{2}$ activation and subsequent cAMP-PKA pathway stimulation enhance the magnitude of LTP at hippocampal CA3-CA1 synapses through AMPAR GluA1-subunit phosphorylation and augment t-LTP at PFC Layers II/III lateral synapses through postsynaptic PKA activation and suppression of $\mathrm{GABA}_{\mathrm{A}}$-mediated inhibitory transmission $[245,246]$. Additionally, the kinase-anchoring protein gravin has been identified-using knockout mice lacking its $\alpha$-isoform which exhibit plasticity and selective memory impairments-as an essential mediator for PKA-induced $\beta_{2}$ receptor phosphorylation and memory formation-associated ERK activation in the hippocampus. This suggests that gravin protein provides a molecular coupling mechanism and shows further interactions between glutamatergic and adrenergic transmission [247]. Similarly, a recent study investigating synergistic cAMP production in response to simultaneous $\beta /$ NMDA receptor activation, using isoprenaline and NMDA respectively as an LTP mechanism, showed that, when $\beta$ adrenoceptor activation precedes NMDARs (by several minutes), it results in the attenuation of the NMDAR-cAMP response that through simulation modelling suggests a novel "Gs-to-Gi" adrenoceptor switch in response to PKA-mediated $\beta_{2}$ receptor phosphorylation and subsequent Gi-mediated adenylyl cyclase inhibition [248]. Lastly, other $\beta_{2}$-mediated plasticity mechanisms have been identified and include the phosphorylative enhancement of L-type VGCC and subsequent LTP induction in addition to the inactivation and removal of dendritic Kv1.1 channels resulting in increased excitability, depolarisation, coincident activity detection and subsequently the facilitation of t-LTP at hippocampal CA3-CA1 synapses $[249,250]$. 


\subsection{Serotonergic Transmission}

Serotonin (5-hydroxy tryptamine, 5-HT) has essential roles in the control of a wide-range of functions including sensory and motor modulation, emotion regulation and cognitive control in addition to its critical involvement in the pathophysiology of various disorders such as migraine, anxiety and depression [251]. The exclusive source of brain serotonin is a group of nuclei (B1-B8) collectively referred to as the Raphe nuclei which project and release serotonin throughout the brain. Serotonin targets seven main receptor types (i.e., $5-\mathrm{HT}_{1-7}$ ) that are further subdivided into at least 14 different subtypes, all of which are GPCRs except for $5-\mathrm{HT}_{3}$ which is an ionotropic receptor permeable to $\mathrm{Na}^{+}, \mathrm{K}^{+}$and $\mathrm{Ca}^{2+}$ ions. Metabotropic serotonin receptors are coupled to different G-proteins including $\mathrm{Gi}\left(5-\mathrm{HT}_{1}\right.$ and 5- $\left.\mathrm{HT}_{5}\right), \mathrm{Gq}\left(5-\mathrm{HT}_{2}\right)$ and $\mathrm{Gs}\left(5-\mathrm{HT}_{4}, 5-\mathrm{HT}_{6}\right.$ and 5- $\left.\mathrm{HT}_{7}\right)$ [252].

The crucial roles of serotonin receptors in learning and memory are well-established; for instance, $5-\mathrm{HT}_{1 \mathrm{~A}}$ is necessary for object recognition memory while $5-\mathrm{HT}_{2 \mathrm{C}}$ is required for stress-induced consolidation of fear memory $[253,254]$. On the other hand, the chronic activation of $5-\mathrm{HT}_{4}$ is found to reverse episodic and spatial memory impairments in mouse models of anxiety and depression in addition to passive avoidance and spatial memory in scopolamine-treated mice $[255,256]$. In contrast, the blockade of $5-\mathrm{HT}_{6}$ receptor enhances object recognition memory, whereas $5-\mathrm{HT}_{7}$ activation improves spatial, cognitive and contextual memory with suggested therapeutic potential in autism and fragile- $X$ syndrome $[257,258]$.

However, serotonin remains the least characterised neuromodulator in relation to its molecular mechanisms of plasticity regulation as most studies do not undertake a receptor subtype-selective approach. Nonetheless, a few studies investigated the roles of $5-\mathrm{HT}_{2}$ receptor and show similar mechanisms to other neuromodulators, in the regulation of glutamatergic transmission and subsequent plasticity induction in various brain regions. In the basolateral amygdala, $5-\mathrm{HT}_{2}$ receptor activation transforms TBS-induced short-term potentiation into LTP through enhanced NMDAR-mediated potentials and calcium influx; consistently, the presynaptic $5-\mathrm{HT}_{2 \mathrm{~A}}$ receptor subtype in the PFC is also shown to enhance NMDAR transmission, thereby gatekeeping subsequent induction of presynaptic t-LTD at corresponding thalamocortical synapses $[259,260]$. Similarly, the application of LFS in the NAcc stimulates serotonin release and LTD induction through $5-\mathrm{HT}_{2}$ receptor-mediated enhancement of L-type VGCC influx and eCB release [261], while in the PFC serotonin facilitates tetanic stimulation-induced NMDAR-independent LTD through 5- $\mathrm{HT}_{2 \mathrm{~A}}$ and group-I mGluR synergistic p38-MAPK activation and subsequent AMPAR internalisation [262].

Lastly, serotonin is able to modulate glutamate and GABA-mediated excitatory and inhibitory transmission, respectively, through various receptor subtype-selective mechanisms such as AMPAR recruitment, NMDAR conductance modulation, cooperative $G_{A B A}$ interaction, $G_{A B A}$ phosphorylation and neurotransmitter release regulation [263].

\section{Astrocytes and Neuromodulators}

Astrocytes are increasingly recognised as active signalling elements that exhibit the abilities to adjust neuronal excitability and synchronous activity [264]. In addition, astrocytes are heavily implicated in synaptic plasticity and are found to undergo plasticity changes in response to neuronal activity [265]. Astrocytic perisynaptic processes express a wide range of receptors the activation of which triggers astrocyte excitation-through the generation of dynamic intracellular $\mathrm{Ca}^{2+}$ transients that rely primarily on the $\mathrm{Gq}-\mathrm{IP}_{3}$ pathway $\left(\mathrm{IP}_{3} \mathrm{R}_{2}\right.$ in astrocytes) —and induces subsequent release of gliotransmitters; thus, providing a bidirectional communication mechanism [266,267]. Moreover, astrocytes express the receptors of, and respond to a vast number of neuromodulators [268]; hence, astrocytes are able to detect and respond to both neuromodulatory signals and neuronal activity.

Accumulating evidence shows that astrocytes are key mediators of neuromodulator actions. In regards to rhythmic activity and synaptic plasticity, astrocytes are critically involved in the regulation of synchronous neuronal activity and associated processes, possibly in response to neuromodulator signals, as astrocytes are found necessary for cognitive flexibility and theta/gamma coupling in 
addition to delta-, alpha- and gamma-power oscillations [269]. Accordingly, astrocytes exhibit neuromodulatory interactions in relation to network activity regulation; for instance, astrocytes respond to septal-released acetylcholine through $\alpha 7-\mathrm{nAchR}$, via increased glutamate release and subsequent activation of hilar interneurons in the dentate gyrus, hence performing an essential intermediary role of septal cholinergic modulation of hippocampal activity [270]. Moreover, noradrenaline in the visual cortex is found necessary for astrocytic sensitisation to localised neuronal activity which occurs in a behaviour-dependent manner [271]. Additionally, it was found in vivo that somatosensory cortex astrocytes show wide spread $\mathrm{Ca}^{2+}$ signalling responses following electrical stimulation of locus coeruleus and peripheral sensory stimulation, through $\alpha$-adrenoceptors, and this response was found independent on sensory-driven glutamatergic pathways [272]. The above findings indicate a potentially central role for astrocytes in the neuromodulation of network activity, synaptic plasticity and sensory signal processing. A schematic representation of astrocytic synaptic coverage in relation to afferent neuromodulatory signals is shown in Figure 2. Despite being key regulators of neuronal transmission and a major target for neuromodulators, astrocytes have not been adequately studied in relation to neuromodulator roles in synaptic plasticity; nonetheless, recent and emerging evidence shows critical roles for astrocytes in various brain regions.

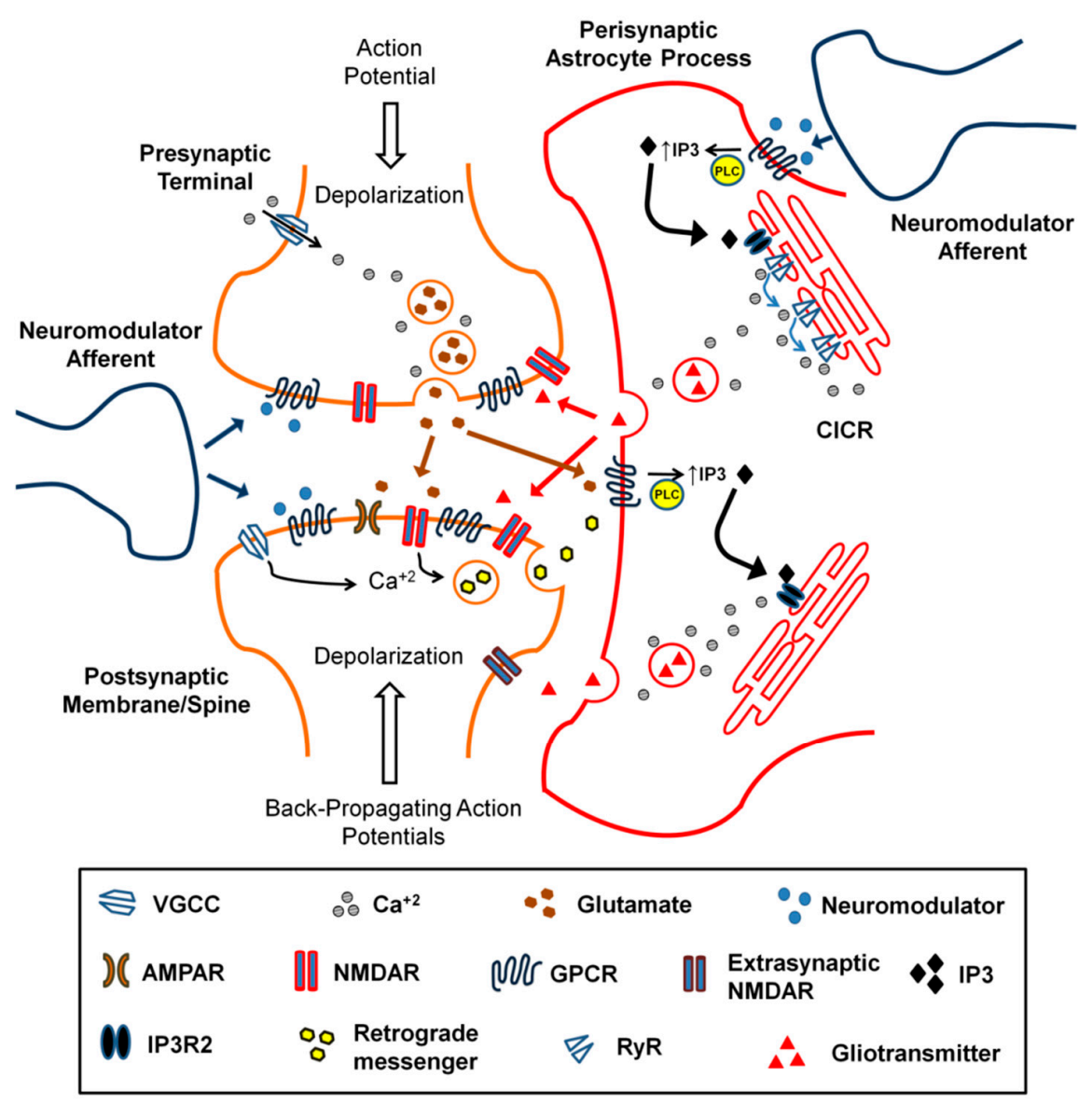

Figure 2. A schematic representation of astrocytic synaptic coverage and neuromodulatory inputs. Astrocytes are able to detect and respond to both synaptic activity and neuromodulatory afferent signals. Neuromodulators and neuron-released transmitters (presynaptic and postsynaptic retrograde messengers) activate associated receptors on perisynaptic astrocyte processes leading to intracellular calcium signalling and subsequent induction of gliotransmitter release to modulate local activity and synaptic plasticity. Similarly, neuromodulatory signals can target neurons, astrocytes or both; hence, neuromodulators transmit behaviour-related signals to induce neuronal activity directly and/or through astrocytes. 
In the hippocampus, the activation of muscarinic receptors is found to induce coincident activity between postsynaptic neurons and astrocytes leading to glutamate release that targets mGluRs to induce LTP which can be prevented via: buffering astrocytic calcium, deleting $\mathrm{IP}_{3} \mathrm{R}_{2}$ receptors which mediate astrocytic intracellular calcium release $\left(\mathrm{IP}_{3} \mathrm{R}_{2}\right.$-kockout mice) or inhibiting G-protein signalling in astrocytes, and mimicked by direct astrocyte stimulation and calcium uncaging when combined with neuronal depolarisation [273]. Furthermore, in the somatosensory cortex, in vivo activation of astrocytic muscarinic receptors following combined NBM and whisker stimulation results in D-serine release and subsequent activation of NMDAR-dependent LTP which was also impaired in $\mathrm{IP}_{3} \mathrm{R}_{2}$-knockout mice [274]. Astrocytic $\alpha_{1}$ adrenoceptor activation induces astrocytic ATP/D-serine release and subsequent LTP induction in the somatosensory cortex [275], while, in the hippocampus, astrocytic but not neuronal $\beta_{2}$ adrenoceptors are necessary for fear memory consolidation [276]. In addition, deleting astrocytic $\beta_{2}$ adrenoceptor significantly impaired learning and hippocampal LTP in aged mice despite intact physical health and motor functions in mutant ones [277]. In relation to dopamine, a subset of astrocytes has been shown to express vesicular monoamine transporter-2 (VMAT2), which is necessary for dopamine homeostasis, and its conditional deletion from astrocytes in the developing PFC is found to impair neurotransmission, executive function and LTP [278].

A recent finding shows that hippocampal t-LTD (induced via LFS combined with postsynaptic depolarisation) is dependent on astrocytic and not neuronal p38 $\alpha$-MAPK which is responsible for increased gliotransmitter (glutamate) release and astrocyte to neuron communication during LTD induction while its selective deletion leads to long-term memory enhancement in vivo [279]. Interestingly, the requirement of p38-MAPK activation has been observed for NMDAR-dependent hippocampal t-LTD previously [280], which was presumed to be purely neuronal. Similarly, endocannabinoids acting as retrograde messengers have been found essential for t-LTD induction at different synapses, for instance, in the hippocampus (CA3-CA1) and developing somatosensory cortex (Layers IV-II/III) through $\mathrm{CB}_{1}$ receptors [281,282]. However, at the same synapses, more recent evidence shows that $t-L T D$ requires endocannabinoid-induced $\mathrm{CB}_{1}$-mediated activation of astrocytic $\mathrm{Ca}^{2+}$ signalling and subsequent gliotransmitter (D-serine/glutamate) release $[283,284]$. These findings indicate that astrocytic control of neuromodulatory actions and synaptic plasticity is critical and necessitate further attention.

\section{Neuromodulators Steer Glutamatergic Transmission and Plasticity}

Experimental findings illustrate various mechanisms by which neuromodulators govern the induction and maintenance of long-term synaptic plasticity across multiple brain regions through steering excitatory glutamatergic transmission on multiple scales. First, at the network level, neuromodulators regulate synchronous neuronal activity thereby fulfilling the first previously-identified criterion for plasticity induction which is associativity (i.e., coincident activity between pre- and post-synaptic neurons) [285]. This is based on the generation of single-band or nested network rhythms mostly representing theta-, alpha- or gamma-power oscillations, which are shown to drive overall network plasticity, synaptic plasticity, STDP and episodic memory [286-288]. In addition, neuromodulator-regulated oscillations across distinct neuronal populations may provide a mechanism for cross-network coupling. This is analogous to the evident role of modulators in input pathway selection that presumably represents a signal amplification and possibly synapse-selection process. The molecular mechanisms underlying the regulation of synchronous neuronal activity are diverse and mostly rely on the spatiotemporal modulation of intrinsic neuronal excitability and regulation of inhibitory transmission [289].

Various neuromodulators have been identified in a considerable number of studies both in vitro and, in particular, in vivo to be essential for the induction of long-term plasticity at specific synapses, which is the second main neuromodulatory function, rather than having a "supplementary" role. This is despite the use of plasticity-inducing stimulation protocols that bypass the requirement of synchronous (i.e., coincident) activity which is one mechanism by which neuromodulators, through rhythmic 
neuronal activity, control synaptic plasticity induction, and therefore indicating other neuromodulatory mechanisms that are critical for induction.

On a synaptic scale, neuromodulators are found to control the activity, strength and dynamics of glutamatergic synapses via multiple similar and modulator-specific mechanisms such as altering glutamate release and ionotropic (i.e., AMPA and NMDA) receptor conductance. Additionally, neuromodulators regulate glutamatergic responses on the cellular level as well; for instance, though adjusting voltage-gated currents, membrane properties and intracellular messenger systems [290]. Accordingly, the third main role for neuromodulators is to gate the induction and control the polarity of plasticity especially in relation to STDP through regulating the threshold and time-window of induction, respectively [291,292].

The fourth key function of neuromodulators in plasticity is based on the previously mentioned "supplementary" role which in the literature is commonly referred to as a plasticity facilitation mechanism. This can take two main forms: the facilitation of plasticity induction following a "sub-threshold" stimulus, which is comparable to the conversion of short-term into long-term plasticity, which presumably reflects acquisition enhancement, or the augmentation of long-term plasticity, specifically LTP, which mostly represents a slow increase in the magnitude of potentiation. The augmentation of LTP has been observed for various neuromodulators and in the vast majority of cases is PKA mediated and expressed via multiple mechanisms in relation to AMPAR and/or NMDAR function. However, the additional PKA component is argued to serve more intriguing and pivotal roles. The first previously-suggested function of PKA is to provide a synaptic tag that would allow the capture of plasticity gene products required for maintenance [293]. The second possible role is based on epigenetic modifications and gene-expression alterations that would arguably serve a memory stabilisation mechanism required for consolidation as seen with noradrenaline and hippocampal LTP maintenance [294,295].

Another key aspect of particular interest in relation to possible plasticity and memory functions is the spatiotemporal release pattern of neuromodulators-reflecting certain tasks and environmental stimuli such as reward, uncertainty and novelty—that is governed by the timing of release, nature of diffusion, duration of action and receptor distribution in target brain region. It is found that the release of neuromodulators is behaviour-dependent and their cognitive functions require a balance of tonic and phasic transmission that rely on tasks and novel/unexpected stimuli, respectively, and that tonic/baseline levels determine phasic transmission responses as observed for noradrenaline [296-298], acetylcholine [299-301], serotonin [302,303] and dopamine [304-307]. Furthermore, tonic levels control phasic actions in an inverted-U-shaped effect in which very low or high background concentrations eliminate phasic-induced responses as observed for dopamine in working memory and cognition [308] in addition to determining the polarity and magnitude of long-term synaptic plasticity [88,307]. Similarly, the inverted-U-shaped effect has been described for acetylcholine, serotonin and noradrenaline as well [309-311] and is a shared neuromodulator property involved in attention-induced neuronal activity modulation [312]. A proposed model for neuromodulatory control of plasticity in relation to behaviour-dependent release patterns is shown in Figure 3.

These findings indicate complex finely-tuned interactions between neuromodulators, especially when considering the intersecting signalling pathways and the relatively slow kinetics of metabotropic regulation when compared to glutamatergic ionotropic transmission, instead of isolated mutually-exclusive functioning [313]. Accordingly, some studies show complex metabotropic neuromodulatory interactions in synaptic plasticity with considerable therapeutic potentials; for instance, amphetamine-induced $\beta$ adrenoceptor activation rescues D1-mediated LTP in the PFC in dopamine transporter knockout mice, which resembles the hyperdopaminergic state in schizophrenia and attention defective disorder [105]. Additionally, the activation of $\mathrm{M}_{4}$ receptor alleviates dyskinetic symptoms and prevents abnormal D1-mediated striatal LTP using an L-DOPA-induced dyskinesia model [314]. On the other hand, antagonising group-I mGluRs alleviates PFC D1-mediated LTP in a mouse model of fragile- $X$ syndrome and improves learning when combined with a D1 agonist [315]. 


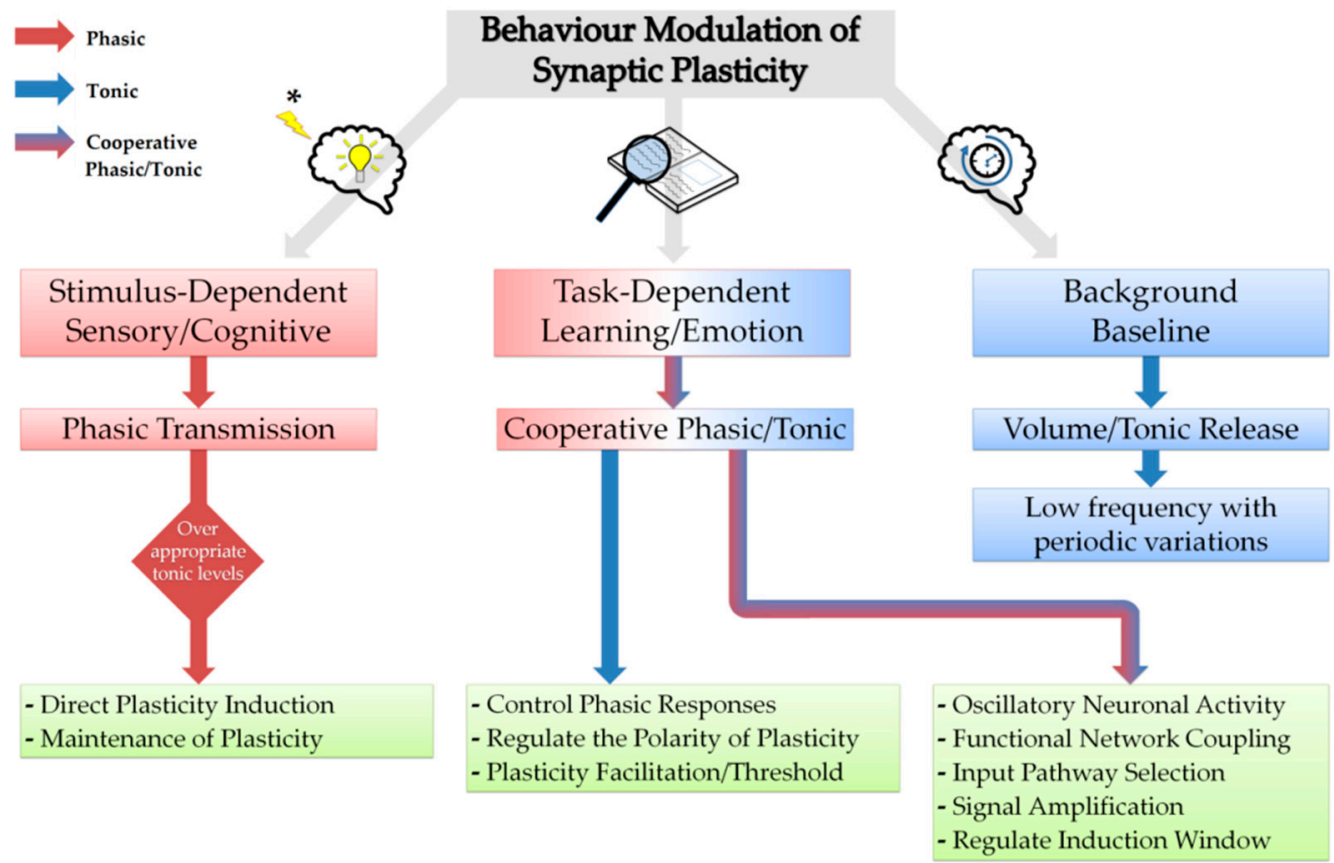

Figure 3. A model of behaviour-dependent neuromodulation of synaptic plasticity. Tonic release of neuromodulators controls baseline and task-induced levels which mediate attention. The cooperative actions of tonic and phasic release during learning tasks modulate network activity and neuronal oscillations that prime plasticity induction through functional coupling, pathway selection and signal amplification. Salient stimuli such as unexpected novelty and reward cues (in rodent models) trigger sub-second phasic transmission to provide the induction/maintenance signal provided that background/tonic levels are "appropriate" for induction. * Salient stimulus.

Another aspect in relation to neuromodulation of transmission and excitatory/inhibitory balance is the plasticity of synaptic inhibition reported in hippocampal pyramidal neurons. This has been observed particularly for $\mathrm{GABA}_{\mathrm{B}}$-mediated slow inhibitory currents through G-protein regulated

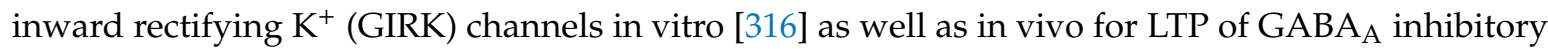
postsynaptic responses with potentially key roles in the control of excessive excitation in early Alzheimer's pathology [317]. Interestingly, GIRK channels are found to be coupled to and regulated by various neuromodulator receptors [318]. Therefore, modulation of synaptic inhibition is another mechanism by which neuromodulators could shape glutamatergic transmission and synaptic plasticity.

The numerous roles of neuromodulators with regard to synaptic plasticity in learning, memory and behavioural functions provide significant insights into the molecular changes underlying certain pathologies, thereby unveiling multiple novel treatment approaches. Alzheimer's disease represents the most challenging disorder in relation to synaptic plasticity impairments due to its complex underlying pathological alterations. Most neuromodulators have been heavily implicated in Alzheimer's disease including other newly investigated modulator-related molecules, the roles of which are still emerging such as neurosteroids, cytokines, neuropeptides and peripherally-derived metabolic regulators. For instance, bile acids have recently been shown to indirectly affect synaptic plasticity and improve Alzheimer's cognitive impairments in rodent models [319,320]. However, the roles of neuromodulators in Alzheimer's disease-associated plasticity impairments remain unclear. Moreover, since Alzheimer's disease is characterised by significant imbalance in neurotransmission and modulation, it is important to understand the interaction between deficits in Alzheimer's disease and how these are affected by current and emerging therapeutic interventions [321,322].

Further research is required to explore behaviour-dependent neuromodulatory interactions and how astrocytes are involved in transmitting modulatory signals into synaptic activity and long-term plasticity. Ultimately, neuromodulators are key participants in synaptic plasticity and associated 
cognitive functions through corresponding GPCRs and their therapeutic potentials extend to cover mood and psychiatric and neurodegenerative diseases.

Author Contributions: Conceptualisation: A.H.B. and H.R.P.; Writing-original draft: A.H.B.; and Writing—review and editing: A.H.B. and H.R.P.

Conflicts of Interest: The authors declare no conflict of interest.

\section{References}

1. Bliss, T.V.; Lømo, T. Long-lasting potentiation of synaptic transmission in the dentate area of the anaesthetized rabbit following stimulation of the perforant path. J. Physiol. 1973, 232, 331-356. [CrossRef] [PubMed]

2. Citri, A.; Malenka, R.C. Synaptic plasticity: Multiple forms, functions, and mechanisms. Neuropsychopharmacology 2008, 33, 18-41. [CrossRef] [PubMed]

3. Holtmaat, A.; Caroni, P. Functional and structural underpinnings of neuronal assembly formation in learning. Nat. Neurosci. 2016, 19, 1553-1562. [CrossRef] [PubMed]

4. Caroni, P.; Donato, F.; Muller, D. Structural plasticity upon learning: Regulation and functions. Nat. Rev. Neurosci. 2012, 13, 478-490. [CrossRef] [PubMed]

5. Abraham, W.C. How long will long-term potentiation last? Phil. Trans. R. Soc. Lond. B 2003, 358, 735-744. [CrossRef] [PubMed]

6. Reymann, K.G.; Frey, J.U. The late maintenance of hippocampal LTP: Requirements, phases,'synaptic tagging','late-associativity'and implications. Neuropharmacology 2007, 52, 24-40. [CrossRef]

7. Wang, H.; Feng, R.; Wang, L.P.; Li, F.; Cao, X.; Tsien, J.Z. CaMKII activation state underlies synaptic labile phase of LTP and short-term memory formation. Curr. Biol. 2008, 18, 1546-1554. [CrossRef]

8. Rossetti, T.; Banerjee, S.; Kim, C.; Leubner, M.; Lamar, C.; Gupta, P.; Lee, B.; Neve, R.; Lisman, J. Memory erasure experiments indicate a critical role of CaMKII in memory storage. Neuron 2017, 96, 207-216. [CrossRef]

9. Juárez-Muñoz, Y.; Ramos-Languren, L.E.; Escobar, M.L. CaMKII Requirement for in Vivo Insular Cortex LTP Maintenance and CTA Memory Persistence. Front. Pharmacol. 2017, 8, 822. [CrossRef]

10. Sanhueza, M.; Lisman, J. The CaMKII/NMDAR complex as a molecular memory. Mol. Brain 2013, 6, 10. [CrossRef]

11. Chen, H.X.; Otmakhov, N.; Strack, S.; Colbran, R.J.; Lisman, J.E. Is persistent activity of calcium/calmodulin-dependent kinase required for the maintenance of LTP? J. Neurophysiol. 2001, 85, 1368-1376. [CrossRef] [PubMed]

12. Murakoshi, H.; Shin, M.E.; Parra-Bueno, P.; Szatmari, E.M.; Shibata, A.C.; Yasuda, R. Kinetics of endogenous CaMKII required for synaptic plasticity revealed by optogenetic kinase inhibitor. Neuron 2017, 94, 37-47. [CrossRef]

13. Buard, I.; Coultrap, S.J.; Freund, R.K.; Lee, Y.S.; Dell'Acqua, M.L.; Silva, A.J.; Bayer, K.U. CaMKII "autonomy" is required for initiating but not for maintaining neuronal long-term information storage. J. Neurosci. 2010, 30, 8214-8220. [CrossRef] [PubMed]

14. Sacktor, T.C.; Fenton, A.A. What does LTP tell us about the roles of CaMKII and PKM $\zeta$ in memory? Mol. Brain 2018, 11, 77. [CrossRef] [PubMed]

15. Squire, L.R.; Barondes, S.H. Anisomycin, like other inhibitors of cerebral protein synthesis, impairs 'long-term'memory of a discrimination task. Brain Res. 1974, 66, 301-308. [CrossRef]

16. Frey, U.; Krug, M.; Reymann, K.G.; Matthies, H. Anisomycin, an inhibitor of protein synthesis, blocks late phases of LTP phenomena in the hippocampal CA1 region in vitro. Brain Res. 1988, 452, 57-65. [CrossRef]

17. Huang, Y.Y.; Li, X.C.; Kandel, E.R. cAMP contributes to mossy fiber LTP by initiating both a covalently mediated early phase and macromolecular synthesis-dependent late phase. Cell 1994, 79, 69-79. [CrossRef]

18. Nguyen, P.V.; Kandel, E.R. A macromolecular synthesis-dependent late phase of long-term potentiation requiring cAMP in the medial perforant pathway of rat hippocampal slices. J. Neurosci. 1996, 16, 3189-3198. [CrossRef]

19. Abate, G.; Colazingari, S.; Accoto, A.; Conversi, D.; Bevilacqua, A. Dendritic spine density and EphrinB2 levels of hippocampal and anterior cingulate cortex neurons increase sequentially during formation of recent and remote fear memory in the mouse. Behav. Brain Res. 2018, 344, 120-131. [CrossRef] 
20. Lu, Y.; Christian, K.; Lu, B. BDNF: A key regulator for protein synthesis-dependent LTP and long-term memory? Neurobiol. Learn. Mem. 2008, 89, 312-323. [CrossRef]

21. Bramham, C.R.; Alme, M.N.; Bittins, M.; Kuipers, S.D.; Nair, R.R.; Pai, B.; Panja, D.; Schubert, M.; Soule, J.; Tiron, A.; et al. The Arc of synaptic memory. Exp. Brain Res. 2010, 200, 125-140. [CrossRef] [PubMed]

22. Sidorov, M.S.; Auerbach, B.D.; Bear, M.F. Fragile $X$ mental retardation protein and synaptic plasticity. Mol. Brain 2013, 6, 15. [CrossRef] [PubMed]

23. Pfeiffer, B.E.; Huber, K.M. Current advances in local protein synthesis and synaptic plasticity. J. Neurosci. 2006, 26, 7147-7150. [CrossRef] [PubMed]

24. Bramham, C.R. Local protein synthesis, actin dynamics, and LTP consolidation. Curr. Opin. Neurobiol. 2008, 18, 524-531. [CrossRef]

25. Park, S.; Park, J.M.; Kim, S.; Kim, J.A.; Shepherd, J.D.; Smith-Hicks, C.L.; Chowdhury, S.; Kaufmann, W.; Kuhl, D.; Ryazanov, A.G.; et al. Elongation factor 2 and fragile X mental retardation protein control the dynamic translation of Arc/Arg3. 1 essential for mGluR-LTD. Neuron 2008, 59, 70-83. [CrossRef]

26. Dore, K.; Aow, J.; Malinow, R. The emergence of NMDA receptor metabotropic function: Insights from imaging. Front. Synaptic Neurosci. 2016, 8, 20. [CrossRef]

27. Grover, L.M.; Teyler, T.J. Two components of long-term potentiation induced by different patterns of afferent activation. Nature 1990, 347, 477-479. [CrossRef]

28. Pigott, B.M.; Garthwaite, J. Nitric oxide is required for L-type $\mathrm{Ca}^{2+}$ channel-dependent long-term potentiation in the hippocampus. Front. Synaptic Neurosci. 2016, 8, 17. [CrossRef]

29. Wang, Y.; Rowan, M.J.; Anwyl, R. Induction of LTD in the dentate gyrus in vitro is NMDA receptor independent, but dependent on $\mathrm{Ca}^{2+}$ influx via low-voltage-activated $\mathrm{Ca}^{2+}$ channels and release of $\mathrm{Ca}^{2+}$ from intracellular stores. J. Neurophysiol. 1997, 77, 812-825. [CrossRef]

30. Wang, H.; Ardiles, A.O.; Yang, S.; Tran, T.; Posada-Duque, R.; Valdivia, G.; Baek, M.; Chuang, Y.A.; Palacios, A.G.; Gallagher, M.; et al. Metabotropic glutamate receptors induce a form of LTP controlled by translation and arc signaling in the hippocampus. J. Neurosci. 2016, 36, 1723-1729. [CrossRef]

31. Daniel, H.; Hemart, N.; Jaillard, D.; Crepel, F. Coactivation of metabotropic glutamate receptors and of voltage-gated calcium channels induces long-term depression in cerebellar Purkinje cells in vitro. Exp. Brain Res. 1992, 90, 327-331. [CrossRef] [PubMed]

32. Liu, M.G.; Kang, S.J.; Shi, T.Y.; Koga, K.; Zhang, M.M.; Collingridge, G.L.; Kaang, B.K.; Zhuo, M. Long-term potentiation of synaptic transmission in the adult mouse insular cortex: Multielectrode array recordings. J. Neurophysiol. 2013, 110, 505-521. [CrossRef] [PubMed]

33. Nguyen, P.V.; Woo, N.H. Regulation of hippocampal synaptic plasticity by cyclic AMP-dependent protein kinases. Prog. Neurobiol. 2003, 71, 401-437. [CrossRef] [PubMed]

34. Sossin, W.S. Isoform specificity of protein kinase Cs in synaptic plasticity. Learn. Mem. 2007, 14, $236-246$. [CrossRef] [PubMed]

35. Hoeffer, C.A.; Klann, E. mTOR signaling: At the crossroads of plasticity, memory and disease. Trends Neurosci. 2010, 33, 67-75. [CrossRef]

36. Horwood, J.M.; Dufour, F.; Laroche, S.; Davis, S. Signalling mechanisms mediated by the phosphoinositide 3-kinase/Akt cascade in synaptic plasticity and memory in the rat. Eur. J. Neurosci. 2006, 23, 3375-3384. [CrossRef]

37. Sweatt, J.D. Mitogen-activated protein kinases in synaptic plasticity and memory. Curr. Opin. Neurobiol. 2004, 14, 311-317. [CrossRef]

38. Araque, A.; Carmignoto, G.; Haydon, P.G.; Oliet, S.H.; Robitaille, R.; Volterra, A. Gliotransmitters travel in time and space. Neuron 2014, 81, 728-739. [CrossRef]

39. De Pittà, M.; Brunel, N.; Volterra, A. Astrocytes: Orchestrating synaptic plasticity? Neuroscience 2016, 323, 43-61. [CrossRef]

40. Rose, C.R.; Konnerth, A. Stores not just for storage: Intracellular calcium release and synaptic plasticity. Neuron 2001, 31, 519-522. [CrossRef]

41. O'Riordan, K.J.; Hu, N.W.; Rowan, M.J. Physiological activation of mGlu5 receptors supports the ion channel function of NMDA receptors in hippocampal LTD induction in vivo. Sci. Rep. 2018, 8, 4391. [CrossRef] [PubMed] 
42. Rosenberg, N.; Gerber, U.; Ster, J. Activation of group II metabotropic glutamate receptors promotes LTP induction at schaffer collateral-CA1 pyramidal cell synapses by priming NMDA receptors. J. Neurosci. 2016, 36, 11521-11531. [CrossRef] [PubMed]

43. Pöschel, B.; Wroblewska, B.; Heinemann, U.; Manahan-Vaughan, D. The metabotropic glutamate receptor mGluR3 is critically required for hippocampal long-term depression and modulates long-term potentiation in the dentate gyrus of freely moving rats. Cereb. Cortex 2005, 15, 1414-1423. [CrossRef] [PubMed]

44. Altinbilek, B.; Manahan-Vaughan, D. Antagonism of group III metabotropic glutamate receptors results in impairment of LTD but not LTP in the hippocampal CA1 region, and prevents long-term spatial memory. Eur. J. Neurosci. 2007, 26, 1166-1172. [CrossRef]

45. Jung, S.J.; Kim, S.J.; Park, Y.K.; Oh, S.B.; Cho, K.; Kim, J. Group I mGluR regulates the polarity of spike-timing dependent plasticity in substantia gelatinosa neurons. Biochem. Biophys. Res. Commun. 2006, 347, 509-516. [CrossRef]

46. Fujii, S.; Sasaki, H.; Mikoshiba, K.; Kuroda, Y.; Yamazaki, Y.; Taufiq, A.M.; Kato, H. A chemical LTP induced by co-activation of metabotropic and N-methyl-D-aspartate glutamate receptors in hippocampal CA1 neurons. Brain Res. 2004, 999, 20-28. [CrossRef]

47. Takeuchi, T.; Duszkiewicz, A.J.; Morris, R.G. The synaptic plasticity and memory hypothesis: Encoding, storage and persistence. Phil. Trans. R. Soc. B. 2014, 369, 20130288. [CrossRef]

48. McGann, J.P. Associative learning and sensory neuroplasticity: How does it happen and what is it good for? Learn. Mem. 2015, 22, 567-576. [CrossRef]

49. Kida, H.; Mitsushima, D. Mechanisms of motor learning mediated by synaptic plasticity in rat primary motor cortex. Neurosci. Res. 2018, 128, 14-18. [CrossRef]

50. Howland, J.G.; Wang, Y.T. Synaptic plasticity in learning and memory: Stress effects in the hippocampus. Prog. Brain. Res. 2008, 169, 145-158.

51. Hong, I.; Kim, J.; Lee, J.; Park, S.; Song, B.; Kim, J.; An, B.; Park, K.; Lee, H.W.; Lee, S.; et al. Reversible plasticity of fear memory-encoding amygdala synaptic circuits even after fear memory consolidation. PLoS ONE 2011, 6, e24260. [CrossRef] [PubMed]

52. Luchkina, N.V.; Bolshakov, V.Y. Mechanisms of fear learning and extinction: Synaptic plasticity-fear memory connection. Psychopharmacology 2019, 236, 163-182. [CrossRef] [PubMed]

53. Bocchio, M.; Nabavi, S.; Capogna, M. Synaptic plasticity, engrams, and network oscillations in amygdala circuits for storage and retrieval of emotional memories. Neuron 2017, 94, 731-743. [CrossRef] [PubMed]

54. Christoffel, D.J.; Golden, S.A.; Russo, S.J. Structural and synaptic plasticity in stress-related disorders. Rev. Neurosci. 2011, 22, 535-549. [CrossRef] [PubMed]

55. Kauer, J.A.; Malenka, R.C. Synaptic plasticity and addiction. Nat. Rev. Neurosci. 2007, 8, 844-858. [CrossRef] [PubMed]

56. Wang, F.; Pereira, A. Neuromodulation, emotional feelings and affective disorders. Mens Sana Monogr. 2016, 14, 5-29.

57. Albensi, B.C.; Oliver, D.R.; Toupin, J.; Odero, G. Electrical stimulation protocols for hippocampal synaptic plasticity and neuronal hyper-excitability: Are they effective or relevant? Exp. Neurol. 2007, 204, 1-13. [CrossRef]

58. Thut, G.; Miniussi, C.; Gross, J. The functional importance of rhythmic activity in the brain. Curr. Biol. 2012, 22, R658-R663. [CrossRef]

59. Noh, N.A. Exploring cortical plasticity and oscillatory brain dynamics via transcranial magnetic stimulation and resting-state electroencephalogram. Malays. J. Med. Sci. 2016, 23, 5-16. [CrossRef]

60. Winson, J. Loss of hippocampal theta rhythm results in spatial memory deficit in the rat. Science 1978, 201, 160-163. [CrossRef]

61. Köster, M.; Finger, H.; Graetz, S.; Kater, M.; Gruber, T. Theta-gamma coupling binds visual perceptual features in an associative memory task. Sci. Rep. 2018, 8, 17688. [CrossRef] [PubMed]

62. Martin, C.; Ravel, N. Beta and gamma oscillatory activities associated with olfactory memory tasks: Different rhythms for different functional networks? Front. Behav. Neurosci. 2014, 8, 218. [CrossRef] [PubMed]

63. Seidenbecher, T.; Laxmi, T.R.; Stork, O.; Pape, H.C. Amygdalar and hippocampal theta rhythm synchronization during fear memory retrieval. Science 2003, 301, 846-850. [CrossRef] [PubMed] 
64. Park, H.; Lee, D.S.; Kang, E.; Kang, H.; Hahm, J.; Kim, J.S.; Chung, C.K.; Jiang, H.; Gross, J.; Jensen, O. Formation of visual memories controlled by gamma power phase-locked to alpha oscillations. Sci. Rep. 2016, 6, 28092. [CrossRef] [PubMed]

65. Ito, H.T.; Schuman, E.M. Frequency-dependent signal transmission and modulation by neuromodulators. Front. Neurosci. 2008, 2, 138-144. [CrossRef]

66. Gu, Z.; Alexander, G.M.; Dudek, S.M.; Yakel, J.L. Hippocampus and entorhinal cortex recruit cholinergic and NMDA receptors separately to generate hippocampal theta oscillations. Cell Rep. 2017, 21, 3585-3595. [CrossRef]

67. Barkus, C.; Line, S.J.; Huber, A.; Capitao, L.; Lima, J.; Jennings, K.; Lowry, J.; Sharp, T.; Bannerman, D.M.; McHugh, S.B. Variation in serotonin transporter expression modulates fear-evoked hemodynamic responses and theta-frequency neuronal oscillations in the amygdala. Biol. Psychiat. 2014, 75, 901-908. [CrossRef]

68. Narayanan, V.; Heiming, R.S.; Jansen, F.; Lesting, J.; Sachser, N.; Pape, H.C.; Seidenbecher, T. Social defeat: Impact on fear extinction and amygdala-prefrontal cortical theta synchrony in 5-HTT deficient mice. PLoS ONE 2011, 6, e22600. [CrossRef]

69. Walling, S.G.; Brown, R.A.; Milway, J.S.; Earle, A.G.; Harley, C.W. Selective tuning of hippocampal oscillations by phasic locus coeruleus activation in awake male rats. Hippocampus 2011, 21, 1250-1262. [CrossRef]

70. Lemon, N.; Aydin-Abidin, S.; Funke, K.; Manahan-Vaughan, D. Locus coeruleus activation facilitates memory encoding and induces hippocampal LTD that depends on $\beta$-adrenergic receptor activation. Cereb. Cortex 2009, 19, 2827-2837. [CrossRef]

71. Andersson, R.H.; Johnston, A.; Herman, P.A.; Winzer-Serhan, U.H.; Karavanova, I.; Vullhorst, D.; Fisahn, A.; Buonanno, A. Neuregulin and dopamine modulation of hippocampal gamma oscillations is dependent on dopamine D4 receptors. Proc. Natl. Acad. Sci. USA 2012, 109, 13118-13123. [CrossRef] [PubMed]

72. Lemercier, C.E.; Schulz, S.B.; Heidmann, K.E.; Kovács, R.; Gerevich, Z. Dopamine D3 receptors inhibit hippocampal gamma oscillations by disturbing CA3 pyramidal cell firing synchrony. Front. Pharmacol. 2016, 6, 297. [CrossRef] [PubMed]

73. O'Carroll, C.M.; Martin, S.J.; Sandin, J.; Frenguelli, B.; Morris, R.G. Dopaminergic modulation of the persistence of one-trial hippocampus-dependent memory. Learn. Mem. 2006, 13, 760-769. [CrossRef] [PubMed]

74. Tononi, G.; Cirelli, C. Sleep function and synaptic homeostasis. Sleep Med. Rev. 2006, 10, 49-62. [CrossRef]

75. Fellin, T.; Halassa, M.M.; Terunuma, M.; Succol, F.; Takano, H.; Frank, M.; Moss, S.J.; Haydon, P.G. Endogenous nonneuronal modulators of synaptic transmission control cortical slow oscillations in vivo. Proc. Natl. Acad. Sci. USA 2009, 106, 15037-15042. [CrossRef]

76. Hill, J.L.; Hardy, N.F.; Jimenez, D.V.; Maynard, K.R.; Kardian, A.S.; Pollock, C.J.; Schloesser, R.J.; Martinowich, K. Loss of promoter IV-driven BDNF expression impacts oscillatory activity during sleep, sensory information processing and fear regulation. Transl. Psychiat. 2016, 6, e873. [CrossRef]

77. Shiromani, P.J.; Basheer, R.; Thakkar, J.; Wagner, D.; Greco, M.A.; Charness, M.E. Sleep and wakefulness in c-fos and fos B gene knockout mice. Mol. Brain Res. 2000, 80, 75-87. [CrossRef]

78. Nieoullon, A. Dopamine and the regulation of cognition and attention. Prog. Neurobiol. 2002, 67, 53-83. [CrossRef]

79. Jaber, M.; Robinson, S.W.; Missale, C.; Caron, M.G. Dopamine receptors and brain function. Neuropharmacology 1996, 35, 1503-1519. [CrossRef]

80. Missale, C.; Nash, S.R.; Robinson, S.W.; Jaber, M.; Caron, M.G. Dopamine receptors: From structure to function. Physiol. Rev. 1998, 78, 189-225. [CrossRef]

81. Fox, M.E.; Mikhailova, M.A.; Bass, C.E.; Takmakov, P.; Gainetdinov, R.R.; Budygin, E.A.; Wightman, R.M. Cross-hemispheric dopamine projections have functional significance. Proc. Natl. Acad. Sci. USA 2016, 113, 6985-6990. [CrossRef] [PubMed]

82. Broussard, J.I. Co-transmission of dopamine and glutamate. J. Gen. Physiol. 2012, 139, 93-96. [CrossRef] [PubMed]

83. Roeper, J. Dissecting the diversity of midbrain dopamine neurons. Trends Neurosci. 2013, 36, 336-342. [CrossRef] [PubMed]

84. Kwon, H.G.; Jang, S.H. Differences in neural connectivity between the substantia nigra and ventral tegmental area in the human brain. Front. Hum. Neurosci. 2014, 8, 41. [CrossRef] 
85. Decot, H.K.; Namboodiri, V.M.; Gao, W.; McHenry, J.A.; Jennings, J.H.; Lee, S.H.; Kantak, P.A.; Kao, Y.C.; Das, M.; Witten, I.B.; et al. Coordination of brain-wide activity dynamics by dopaminergic neurons. Neuropsychopharmacology 2017, 42, 615-627. [CrossRef] [PubMed]

86. Puig, M.; Rose, J.; Schmidt, R.; Freund, N. Dopamine modulation of learning and memory in the prefrontal cortex: Insights from studies in primates, rodents, and birds. Front. Neural Circuit 2014, 8, 93. [CrossRef]

87. Gao, M.; Liu, C.L.; Yang, S.; Jin, G.Z.; Bunney, B.S.; Shi, W.X. Functional coupling between the prefrontal cortex and dopamine neurons in the ventral tegmental area. J. Neurosci. 2007, 27, 5414-5421. [CrossRef]

88. Sheynikhovich, D.; Otani, S.; Arleo, A. The role of tonic and phasic dopamine for long-term synaptic plasticity in the prefrontal cortex: A computational model. J. Physiol. Paris 2011, 105, 45-52. [CrossRef]

89. Sheynikhovich, D.; Otani, S.; Arleo, A. Dopaminergic control of long-term depression/long-term potentiation threshold in prefrontal cortex. J. Neurosci. 2013, 33, 13914-13926. [CrossRef]

90. Huang, Y.Y.; Simpson, E.; Kellendonk, C.; Kandel, E.R. Genetic evidence for the bidirectional modulation of synaptic plasticity in the prefrontal cortex by D1 receptors. Proc. Natl. Acad. Sci. USA 2004, 101, 3236-3241. [CrossRef]

91. Gurden, H.; Takita, M.; Jay, T.M. Essential role of D1 but not D2 receptors in the NMDA receptor-dependent long-term potentiation at hippocampal-prefrontal cortex synapses in vivo. J. Neurosci. 2000, 20, RC106. [CrossRef] [PubMed]

92. Gurden, H.; Tassin, J.P.; Jay, T.M. Integrity of the mesocortical dopaminergic system is necessary for complete expression of in vivo hippocampal-prefrontal cortex long-term potentiation. Neuroscience 1999, 94, 1019-1027. [CrossRef]

93. Law-Tho, D.; Desce, J.M.; Crepel, F. Dopamine favours the emergence of long-term depression versus long-term potentiation in slices of rat prefrontal cortex. Neurosci. Lett. 1995, 188, 125-128. [CrossRef]

94. Matsuda, Y.; Marzo, A.; Otani, S. The presence of background dopamine signal converts long-term synaptic depression to potentiation in rat prefrontal cortex. J. Neurosci. 2006, 26, 4803-4810. [CrossRef]

95. Otani, S.; Auclair, N.; Desce, J.M.; Roisin, M.P.; Crépel, F. Dopamine receptors and groups I and II mGluRs cooperate for long-term depression induction in rat prefrontal cortex through converging postsynaptic activation of MAP kinases. J. Neurosci. 1999, 19, 9788-9802. [CrossRef]

96. Xu, T.X.; Yao, W.D. D1 and D2 dopamine receptors in separate circuits cooperate to drive associative long-term potentiation in the prefrontal cortex. Proc. Natl. Acad. Sci. USA 2010, 107, 16366-16371. [CrossRef]

97. Laroche, S.; Davis, S.; Jay, T.M. Plasticity at hippocampal to prefrontal cortex synapses: Dual roles in working memory and consolidation. Hippocampus 2000, 10, 438-446. [CrossRef]

98. Banks, P.J.; Burroughs, A.C.; Barker, G.R.; Brown, J.T.; Warburton, E.C.; Bashir, Z.I. Disruption of hippocampal-prefrontal cortex activity by dopamine D2R-dependent LTD of NMDAR transmission. Proc. Natl. Acad. Sci. USA 2015, 112, 11096-11101. [CrossRef]

99. Seamans, J.K.; Durstewitz, D.; Christie, B.R.; Stevens, C.F.; Sejnowski, T.J. Dopamine D1/D5 receptor modulation of excitatory synaptic inputs to layer V prefrontal cortex neurons. Proc. Natl. Acad. Sci. USA 2001, 98, 301-306. [CrossRef]

100. Gao, C.; Wolf, M.E. Dopamine receptors regulate NMDA receptor surface expression in prefrontal cortex neurons. J. Neurochem. 2008, 106, 2489-2501. [CrossRef]

101. Sun, X.; Zhao, Y.; Wolf, M.E. Dopamine receptor stimulation modulates AMPA receptor synaptic insertion in prefrontal cortex neurons. J. Neurosci. 2005, 25, 7342-7351. [CrossRef] [PubMed]

102. Kruse, M.S.; Prémont, J.; Krebs, M.O.; Jay, T.M. Interaction of dopamine D1 with NMDA NR1 receptors in rat prefrontal cortex. Eur. Neuropsychopharmacol. 2009, 19, 296-304. [CrossRef] [PubMed]

103. Yuen, E.Y.; Yan, Z. Dopamine D4 receptors regulate AMPA receptor trafficking and glutamatergic transmission in GABAergic interneurons of prefrontal cortex. J. Neurosci. 2009, 29, 550-562. [CrossRef] [PubMed]

104. Zhong, P.; Yan, Z. Distinct physiological effects of dopamine D4 receptors on prefrontal cortical pyramidal neurons and fast-spiking interneurons. Cereb. Cortex 2014, 26, 180-191. [CrossRef]

105. Xu, T.X.; Ma, Q.; Spealman, R.D.; Yao, W.D. Amphetamine modulation of long-term potentiation in the prefrontal cortex: Dose dependency, monoaminergic contributions, and paradoxical rescue in hyperdopaminergic mutant. J. Neurochem. 2010, 115, 1643-1654. [CrossRef]

106. Bai, J.; Blot, K.; Tzavara, E.; Nosten-Bertrand, M.; Giros, B.; Otani, S. Inhibition of dopamine transporter activity impairs synaptic depression in rat prefrontal cortex through over-stimulation of D1 receptors. Cereb. Cortex 2012, 24, 945-955. [CrossRef] 
107. Zhang, B.; Guo, F.; Ma, Y.; Song, Y.; Lin, R.; Shen, F.Y.; Jin, G.Z.; Li, Y.; Liu, Z.Q. Activation of D1R/PKA/mTOR signaling cascade in medial prefrontal cortex underlying the antidepressant effects of l-SPD. Sci. Rep. 2017, 7, 3809. [CrossRef]

108. Molina-Luna, K.; Pekanovic, A.; Röhrich, S.; Hertler, B.; Schubring-Giese, M.; Rioult-Pedotti, M.S.; Luft, A.R. Dopamine in motor cortex is necessary for skill learning and synaptic plasticity. PLoS ONE 2009, 4, e7082. [CrossRef]

109. Hosp, J.A.; Pekanovic, A.; Rioult-Pedotti, M.S.; Luft, A.R. Dopaminergic projections from midbrain to primary motor cortex mediate motor skill learning. J. Neurosci. 2011, 31, 2481-2487. [CrossRef]

110. Rioult-Pedotti, M.S.; Pekanovic, A.; Atiemo, C.O.; Marshall, J.; Luft, A.R. Dopamine promotes motor cortex plasticity and motor skill learning via PLC activation. PLoS ONE 2015, 10, e0124986. [CrossRef]

111. Hosp, J.A.; Luft, A.R. Dopaminergic meso-cortical projections to M1: Role in motor learning and motor cortex plasticity. Front. Neurol. 2013, 4, 145. [CrossRef] [PubMed]

112. Hosp, J.A.; Molina-Luna, K.; Hertler, B.; Atiemo, C.O.; Luft, A.R. Dopaminergic modulation of motor maps in rat motor cortex: An in vivo study. Neuroscience 2009, 159, 692-700. [CrossRef] [PubMed]

113. Li, Q.; Ko, H.; Qian, Z.M.; Yan, L.Y.; Chan, D.C.; Arbuthnott, G.; Ke, Y.; Yung, W.H. Refinement of learned skilled movement representation in motor cortex deep output layer. Nat. Commun. 2017, 8, 15834. [CrossRef] [PubMed]

114. Balleine, B.W.; Delgado, M.R.; Hikosaka, O. The role of the dorsal striatum in reward and decision-making. J. Neurosci. 2007, 27, 8161-8165. [CrossRef] [PubMed]

115. Tepper, J.M.; Tecuapetla, F.; Koós, T.; Ibáñez-Sandoval, O. Heterogeneity and diversity of striatal GABAergic interneurons. Front. Neuroanat. 2010, 4, 150. [CrossRef]

116. Routtenberg, A.; Holzman, N. Memory disruption by electrical stimulation of substantia nigra, pars compacta. Science 1973, 181, 83-86. [CrossRef]

117. Da Cunha, C.; Wietzikoski, S.; Wietzikoski, E.C.; Miyoshi, E.; Ferro, M.M.; Anselmo-Franci, J.A.; Canteras, N.S. Evidence for the substantia nigra pars compacta as an essential component of a memory system independent of the hippocampal memory system. Neurobiol. Learn. Mem. 2003, 79, 236-242. [CrossRef]

118. Ramayya, A.G.; Misra, A.; Baltuch, G.H.; Kahana, M.J. Microstimulation of the human substantia nigra alters reinforcement learning. J. Neurosci. 2014, 34, 6887-6895. [CrossRef]

119. de Berker, A.O.; Rutledge, R.B. A role for the human substantia nigra in reinforcement learning. J. Neurosci. 2014, 34, 12947-12949. [CrossRef]

120. Beal, M.F. Experimental models of Parkinson's disease. Nat. Rev. Neurosci. 2001, 2, 325-332. [CrossRef]

121. Bové, J.; Prou, D.; Perier, C.; Przedborski, S. Toxin-induced models of Parkinson's disease. NeuroRx 2005, 2, 484-494. [CrossRef] [PubMed]

122. Suppa, A.; Marsili, L.; Belvisi, D.; Conte, A.; Iezzi, E.; Modugno, N.; Fabbrini, G.; Berardelli, A. Lack of LTP-like plasticity in primary motor cortex in Parkinson's disease. Exp. Neurol. 2011, 227, 296-301. [CrossRef] [PubMed]

123. Pisani, A.; Centonze, D.; Bernardi, G.; Calabresi, P. Striatal synaptic plasticity: Implications for motor learning and Parkinson's disease. Mov. Disord. 2005, 20, 395-402. [CrossRef] [PubMed]

124. Paillé, V.; Picconi, B.; Bagetta, V.; Ghiglieri, V.; Sgobio, C.; Di Filippo, M.; Viscomi, M.T.; Giampà, C.; Fusco, F.R.; Gardoni, F.; et al. Distinct levels of dopamine denervation differentially alter striatal synaptic plasticity and NMDA receptor subunit composition. J. Neurosci. 2010, 30, 14182-14193.

125. Rylander, D.; Bagetta, V.; Pendolino, V.; Zianni, E.; Grealish, S.; Gardoni, F.; Di Luca, M.; Calabresi, P.; Cenci, M.A.; Picconi, B. Region-specific restoration of striatal synaptic plasticity by dopamine grafts in experimental parkinsonism. Proc. Natl. Acad. Sci. USA 2013, 110, E4375-E4384. [CrossRef]

126. Kishore, A.; Joseph, T.; Velayudhan, B.; Popa, T.; Meunier, S. Early, severe and bilateral loss of LTP and LTD-like plasticity in motor cortex (M1) in de novo Parkinson's disease. Clin. Neurophysiol. 2012, 123, 822-828. [CrossRef]

127. Morgante, F.; Espay, A.J.; Gunraj, C.; Lang, A.E.; Chen, R. Motor cortex plasticity in Parkinson's disease and levodopa-induced dyskinesias. Brain 2006, 129, 1059-1069. [CrossRef]

128. Thiele, S.L.; Chen, B.; Lo, C.; Gertler, T.S.; Warre, R.; Surmeier, J.D.; Brotchie, J.M.; Nash, J.E. Selective loss of bi-directional synaptic plasticity in the direct and indirect striatal output pathways accompanies generation of parkinsonism and 1-DOPA induced dyskinesia in mouse models. Neurobiol. Dis. 2014, 71, 334-344. [CrossRef] 
129. Hawes, S.L.; Gillani, F.; Evans, R.C.; Benkert, E.A.; Blackwell, K.T. Sensitivity to theta-burst timing permits LTP in dorsal striatal adult brain slice. J. Neurophysiol. 2013, 110, 2027-2036. [CrossRef]

130. Kerr, J.N.; Wickens, J.R. Dopamine D-1/D-5 receptor activation is required for long-term potentiation in the rat neostriatum in vitro. J. Neurophysiol. 2001, 85, 117-124. [CrossRef]

131. Calabresi, P.; Gubellini, P.; Centonze, D.; Picconi, B.; Bernardi, G.; Chergui, K.; Svenningsson, P.; Fienberg, A.A.; Greengard, P. Dopamine and CAMP-regulated phosphoprotein $32 \mathrm{kDa}$ controls both striatal long-term depression and long-term potentiation, opposing forms of synaptic plasticity. J. Neurosci. 2000, 20, 8443-8451. [CrossRef] [PubMed]

132. Xu, H.; Perez, S.; Cornil, A.; Detraux, B.; Prokin, I.; Cui, Y.; Degos, B.; Berry, H.; de Kerchove d'Exaerde, A.; Venance, L. Dopamine-endocannabinoid interactions mediate spike-timing-dependent potentiation in the striatum. Nat. Commun. 2018, 9, 4118. [CrossRef] [PubMed]

133. Wu, Y.W.; Kim, J.I.; Tawfik, V.L.; Lalchandani, R.R.; Scherrer, G.; Ding, J.B. Input-and cell-type-specific endocannabinoid-dependent LTD in the striatum. Cell Rep. 2015, 10, 75-87. [CrossRef] [PubMed]

134. Pawlak, V.; Kerr, J.N. Dopamine receptor activation is required for corticostriatal spike-timing-dependent plasticity. J. Neurosci. 2008, 28, 2435-2446. [CrossRef]

135. Gerfen, C.R.; Surmeier, D.J. Modulation of striatal projection systems by dopamine. Annu. Rev. Neurosci. 2011, 34, 441-466. [CrossRef]

136. Cerovic, M.; d'Isa, R.; Tonini, R.; Brambilla, R. Molecular and cellular mechanisms of dopamine-mediated behavioral plasticity in the striatum. Neurobiol. Learn. Mem. 2013, 105, 63-80. [CrossRef]

137. Colelli, V.; Fiorenza, M.T.; Conversi, D.; Orsini, C.; Cabib, S. Strain-specific proportion of the two isoforms of the dopamine D2 receptor in the mouse striatum: Associated neural and behavioral phenotypes. Genes Brain Behav. 2010, 9, 703-711. [CrossRef]

138. Surmeier, D.J.; Ding, J.; Day, M.; Wang, Z.; Shen, W. D1 and D2 dopamine-receptor modulation of striatal glutamatergic signaling in striatal medium spiny neurons. Trends Neurosci. 2007, 30, 228-235. [CrossRef]

139. Tritsch, N.X.; Sabatini, B.L. Dopaminergic modulation of synaptic transmission in cortex and striatum. Neuron 2012, 76, 33-50. [CrossRef]

140. Setlow, B. The nucleus accumbens and learning and memory. J. Neurosci. Res. 1997, 49, 515-521. [CrossRef]

141. Salamone, J.D.; Correa, M. Motivational views of reinforcement: Implications for understanding the behavioral functions of nucleus accumbens dopamine. Behav. Brain Res. 2002, 137, 3-25. [CrossRef]

142. Brady, A.M.; O'Donnell, P. Dopaminergic modulation of prefrontal cortical input to nucleus accumbens neurons in vivo. J. Neurosci. 2004, 24, 1040-1049. [CrossRef] [PubMed]

143. Floresco, S.B.; Blaha, C.D.; Yang, C.R.; Phillips, A.G. Modulation of hippocampal and amygdalar-evoked activity of nucleus accumbens neurons by dopamine: Cellular mechanisms of input selection. J. Neurosci. 2001, 21, 2851-2860. [CrossRef] [PubMed]

144. Pinto, A.; Jankowski, M.; Sesack, S.R. Projections from the paraventricular nucleus of the thalamus to the rat prefrontal cortex and nucleus accumbens shell: Ultrastructural characteristics and spatial relationships with dopamine afferents. J. Comp. Neurol. 2003, 459, 142-155. [CrossRef] [PubMed]

145. Britt, J.P.; Benaliouad, F.; McDevitt, R.A.; Stuber, G.D.; Wise, R.A.; Bonci, A. Synaptic and behavioral profile of multiple glutamatergic inputs to the nucleus accumbens. Neuron 2012, 76, 790-803. [CrossRef] [PubMed]

146. Zhu, Y.; Wienecke, C.F.; Nachtrab, G.; Chen, X. A thalamic input to the nucleus accumbens mediates opiate dependence. Nature 2016, 530, 219-222. [CrossRef]

147. Stuber, G.D.; Sparta, D.R.; Stamatakis, A.M.; van Leeuwen, W.A.; Hardjoprajitno, J.E.; Cho, S.; Tye, K.M.; Kempadoo, K.A.; Zhang, F.; Deisseroth, K.; et al. Excitatory transmission from the amygdala to nucleus accumbens facilitates reward seeking. Nature 2011, 475, 377-380. [CrossRef]

148. Schacter, G.B.; Yang, C.R.; Innis, N.K.; Mogenson, G.J. The role of the hippocampal-nucleus accumbens pathway in radial-arm maze performance. Brain Res. 1989, 494, 339-349. [CrossRef]

149. LeGates, T.A.; Kvarta, M.D.; Tooley, J.R.; Francis, T.C.; Lobo, M.K.; Creed, M.C.; Thompson, S.M. Reward behaviour is regulated by the strength of hippocampus-nucleus accumbens synapses. Nature 2018, 564, 258-262. [CrossRef]

150. Luís, C.; Cannella, N.; Spanagel, R.; Köhr, G. Persistent strengthening of the prefrontal cortex-nucleus accumbens pathway during incubation of cocaine-seeking behavior. Neurobiol. Learn. Mem. 2017, 138, 281-290. [CrossRef] 
151. Qi, J.; Zhang, S.; Wang, H.L.; Barker, D.J.; Miranda-Barrientos, J.; Morales, M. VTA glutamatergic inputs to nucleus accumbens drive aversion by acting on GABAergic interneurons. Nat. Neurosci. 2016, 19, 725-733. [CrossRef] [PubMed]

152. French, S.J.; Totterdell, S. Hippocampal and prefrontal cortical inputs monosynaptically converge with individual projection neurons of the nucleus accumbens. J. Comp. Neurol. 2002, 446, 151-165. [CrossRef] [PubMed]

153. Ito, R.; Hayen, A. Opposing roles of nucleus accumbens core and shell dopamine in the modulation of limbic information processing. J. Neurosci. 2011, 31, 6001-6007. [CrossRef] [PubMed]

154. Taverna, S.; Canciani, B.; Pennartz, C.M. Dopamine D1-receptors modulate lateral inhibition between principal cells of the nucleus accumbens. J. Neurophysiol. 2005, 93, 1816-1819. [CrossRef] [PubMed]

155. Mele, A.; Avena, M.; Roullet, P.; De Leonibus, E.; Mandillo, S.; Sargolini, F.; Coccurello, R.; Oliverio, A. Nucleus accumbens dopamine receptors in the consolidation of spatial memory. Behav. Pharmacol. 2004, 15, 423-431. [CrossRef]

156. Smith-Roe, S.L.; Kelley, A.E. Coincident activation of NMDA and dopamine D1Receptors within the nucleus accumbens core is required for appetitive instrumental learning. J. Neurosci. 2000, 20, 7737-7742. [CrossRef]

157. Fadok, J.P.; Darvas, M.; Dickerson, T.M.; Palmiter, R.D. Long-term memory for pavlovian fear conditioning requires dopamine in the nucleus accumbens and basolateral amygdala. PLoS ONE 2010, 5, e12751. [CrossRef]

158. Yawata, S.; Yamaguchi, T.; Danjo, T.; Hikida, T.; Nakanishi, S. Pathway-specific control of reward learning and its flexibility via selective dopamine receptors in the nucleus accumbens. Proc. Natl. Acad. Sci. USA 2012, 109, 12764-12769. [CrossRef]

159. Ng, E.; Varaschin, R.K.; Su, P.; Browne, C.J.; Hermainski, J.; Le Foll, B.; Pongs, O.; Liu, F.; Trudeau, L.E.; Roder, J.C.; et al. Neuronal calcium sensor-1 deletion in the mouse decreases motivation and dopamine release in the nucleus accumbens. Behav. Brain Res. 2016, 301, 213-225. [CrossRef]

160. Chao, S.Z.; Ariano, M.A.; Peterson, D.A.; Wolf, M.E. D1 dopamine receptor stimulation increases GluR1 surface expression in nucleus accumbens neurons. J. Neurochem. 2002, 83, 704-712. [CrossRef]

161. Chao, S.Z.; Lu, W.; Lee, H.K.; Huganir, R.L.; Wolf, M.E. D1 dopamine receptor stimulation increases GluR1 phosphorylation in postnatal nucleus accumbens cultures. J. Neurochem. 2002, 81, 984-992. [CrossRef] [PubMed]

162. Mangiavacchi, S.; Wolf, M.E. D1 dopamine receptor stimulation increases the rate of AMPA receptor insertion onto the surface of cultured nucleus accumbens neurons through a pathway dependent on protein kinase A. J. Neurochem. 2004, 88, 1261-1271. [CrossRef] [PubMed]

163. Wolf, M.E. Regulation of AMPA receptor trafficking in the nucleus accumbens by dopamine and cocaine. Neurotox. Res. 2010, 18, 393-409. [CrossRef] [PubMed]

164. Yagishita, S.; Hayashi-Takagi, A.; Ellis-Davies, G.C.; Urakubo, H.; Ishii, S.; Kasai, H. A critical time window for dopamine actions on the structural plasticity of dendritic spines. Science 2014, 345, 1616-1620. [CrossRef] [PubMed]

165. Yamaguchi, T.; Goto, A.; Nakahara, I.; Yawata, S.; Hikida, T.; Matsuda, M.; Funabiki, K.; Nakanishi, S. Role of PKA signaling in D2 receptor-expressing neurons in the core of the nucleus accumbens in aversive learning. Proc. Natl. Acad. Sci. USA 2015, 112, 11383-11388. [CrossRef] [PubMed]

166. Schotanus, S.M.; Chergui, K. Dopamine D1 receptors and group I metabotropic glutamate receptors contribute to the induction of long-term potentiation in the nucleus accumbens. Neuropharmacology 2008, 54, 837-844. [CrossRef] [PubMed]

167. Russo, S.J.; Dietz, D.M.; Dumitriu, D.; Morrison, J.H.; Malenka, R.C.; Nestler, E.J. The addicted synapse: Mechanisms of synaptic and structural plasticity in nucleus accumbens. Trends Neurosci. 2010, 33, 267-276. [CrossRef]

168. Volkow, N.D.; Wise, R.A.; Baler, R. The dopamine motive system: Implications for drug and food addiction. Nat. Rev. Neurosci. 2017, 18, 741-752. [CrossRef]

169. Neves, G.; Cooke, S.F.; Bliss, T.V. Synaptic plasticity, memory and the hippocampus: A neural network approach to causality. Nat. Rev. Neurosci. 2008, 9, 65-75. [CrossRef]

170. Kempadoo, K.A.; Mosharov, E.V.; Choi, S.J.; Sulzer, D.; Kandel, E.R. Dopamine release from the locus coeruleus to the dorsal hippocampus promotes spatial learning and memory. Proc. Natl. Acad. Sci. USA 2016, 113, 14835-14840. [CrossRef] 
171. Shohamy, D.; Adcock, R.A. Dopamine and adaptive memory. Trends. Cogn. Sci. 2010, 14, 464-472. [CrossRef] [PubMed]

172. Fanselow, M.S.; Dong, H.W. Are the dorsal and ventral hippocampus functionally distinct structures? Neuron 2010, 65, 7-19. [CrossRef] [PubMed]

173. Duszkiewicz, A.J.; McNamara, C.G.; Takeuchi, T.; Genzel, L. Novelty and dopaminergic modulation of memory persistence: A tale of two systems. Trends Neurosci. 2019, 42, 102-114. [CrossRef] [PubMed]

174. Li, S.; Cullen, W.K.; Anwyl, R.; Rowan, M.J. Dopamine-dependent facilitation of LTP induction in hippocampal CA1 by exposure to spatial novelty. Nat. Neurosci. 2003, 6, 526-531. [CrossRef]

175. Takeuchi, T.; Duszkiewicz, A.J.; Sonneborn, A.; Spooner, P.A.; Yamasaki, M.; Watanabe, M.; Smith, C.C.; Fernández, G.; Deisseroth, K.; Greene, R.W.; et al. Locus coeruleus and dopaminergic consolidation of everyday memory. Nature 2016, 537, 357-362. [CrossRef]

176. Heath, F.C.; Jurkus, R.; Bast, T.; Pezze, M.A.; Lee, J.L.; Voigt, J.P.; Stevenson, C.W. Dopamine D1-like receptor signalling in the hippocampus and amygdala modulates the acquisition of contextual fear conditioning. Psychopharmacology 2015, 232, 2619-2629. [CrossRef]

177. Nyberg, L.; Karalija, N.; Salami, A.; Andersson, M.; Wåhlin, A.; Kaboovand, N.; Köhncke, Y.; Axelsson, J.; Rieckmann, A.; Papenberg, G.; et al. Dopamine D2 receptor availability is linked to hippocampal-caudate functional connectivity and episodic memory. Proc. Natl. Acad. Sci. USA 2016, 113, 7918-7923. [CrossRef]

178. Smith, W.B.; Starck, S.R.; Roberts, R.W.; Schuman, E.M. Dopaminergic stimulation of local protein synthesis enhances surface expression of GluR1 and synaptic transmission in hippocampal neurons. Neuron 2005, 45, 765-779. [CrossRef]

179. Frey, U.; Matthies, H.; Reymann, K.G.; Matthies, H. The effect of dopaminergic D1 receptor blockade during tetanization on the expression of long-term potentiation in the rat CA1 region in vitro. Neurosci. Lett. 1991, 129, 111-114. [CrossRef]

180. Huang, Y.Y.; Kandel, E.R. D1/D5 receptor agonists induce a protein synthesis-dependent late potentiation in the CA1 region of the hippocampus. Proc. Natl. Acad. Sci. USA 1995, 92, 2446-2450. [CrossRef]

181. Navakkode, S.; Sajikumar, S.; Frey, J.U. Synergistic requirements for the induction of dopaminergic D1/D5-receptor-mediated LTP in hippocampal slices of rat CA1 in vitro. Neuropharmacology 2007, 52, 1547-1554. [CrossRef] [PubMed]

182. Otmakhova, N.A.; Lisman, J.E. D1/D5 dopamine receptor activation increases the magnitude of early long-term potentiation at CA1 hippocampal synapses. J. Neurosci. 1996, 16, 7478-7486. [CrossRef] [PubMed]

183. Shetty, M.S.; Sajikumar, S. Differential involvement of $\mathrm{Ca}^{2+} /$ calmodulin-dependent protein kinases and mitogen-activated protein kinases in the dopamine D1/D5 receptor-mediated potentiation in hippocampal CA1 pyramidal neurons. Neurobiol. Learn. Mem. 2017, 138, 111-120. [CrossRef] [PubMed]

184. Lemon, N.; Manahan-Vaughan, D. Dopamine D1/D5 receptors gate the acquisition of novel information through hippocampal long-term potentiation and long-term depression. J. Neurosci. 2006, 26, 7723-7729. [CrossRef]

185. Rocchetti, J.; Isingrini, E.; Dal Bo, G.; Sagheby, S.; Menegaux, A.; Tronche, F.; Levesque, D.; Moquin, L.; Gratton, A.; Wong, T.P.; et al. Presynaptic D2 dopamine receptors control long-term depression expression and memory processes in the temporal hippocampus. Biol. Psychiat. 2015, 77, 513-525. [CrossRef]

186. Liu, J.; Wang, W.; Wang, F.; Cai, F.; Hu, Z.L.; Yang, Y.J.; Chen, J.; Chen, J.G. Phosphatidylinositol-linked novel D1 dopamine receptor facilitates long-term depression in rat hippocampal CA1 synapses. Neuropharmacology 2009, 57, 164-171. [CrossRef]

187. Swant, J.; Wagner, J.J. Dopamine transporter blockade increases LTP in the CA1 region of the rat hippocampus via activation of the D3 dopamine receptor. Learn. Mem. 2006, 13, 161-167. [CrossRef]

188. Kwon, O.B.; Paredes, D.; Gonzalez, C.M.; Neddens, J.; Hernandez, L.; Vullhorst, D.; Buonanno, A. Neuregulin-1 regulates LTP at CA1 hippocampal synapses through activation of dopamine D4 receptors. Proc. Natl. Acad. Sci. USA 2008, 105, 15587-15592. [CrossRef]

189. Hasselmo, M.E. The role of acetylcholine in learning and memory. Curr. Opin. Neurobiol. 2006, 16, 710-715. [CrossRef]

190. Hurst, R.; Rollema, H.; Bertrand, D. Nicotinic acetylcholine receptors: From basic science to therapeutics. Pharmacol. Therapeut. 2013, 137, 22-54. [CrossRef]

191. Parri, H.R.; Hernandez, C.M.; Dineley, K.T. Research update: Alpha7 nicotinic acetylcholine receptor mechanisms in Alzheimer's disease. Biochem. Pharmacol. 2011, 82, 931-942. [CrossRef] [PubMed] 
192. Nikiforuk, A.; Kos, T.; Potasiewicz, A.; Popik, P. Positive allosteric modulation of alpha 7 nicotinic acetylcholine receptors enhances recognition memory and cognitive flexibility in rats. Eur. Neuropsychopharmacol. 2015, 25, 1300-1313. [CrossRef] [PubMed]

193. Volpicelli, L.A.; Levey, A.I. Muscarinic acetylcholine receptor subtypes in cerebral cortex and hippocampus. Prog. Brain Res. 2004, 145, 59-66. [PubMed]

194. Záborszky, L.; Gombkoto, P.; Varsanyi, P.; Gielow, M.R.; Poe, G.; Role, L.W.; Ananth, M.; Rajebhosale, P.; Talmage, D.A.; Hasselmo, M.E.; et al. Specific Basal Forebrain-Cortical Cholinergic Circuits Coordinate Cognitive Operations. J. Neurosci. 2018, 38, 9446-9458.

195. Mori, F.; Okada, K.I.; Nomura, T.; Kobayashi, Y. The pedunculopontine tegmental nucleus as a motor and cognitive interface between the cerebellum and basal ganglia. Front. Neuroanat. 2016, 10, 109. [CrossRef]

196. Deffains, M.; Bergman, H. Striatal cholinergic interneurons and cortico-striatal synaptic plasticity in health and disease. Mov. Disord. 2015, 30, 1014-1025. [CrossRef]

197. Easton, A.; Douchamps, V.; Eacott, M.; Lever, C. A specific role for septohippocampal acetylcholine in memory? Neuropsychologia 2012, 50, 3156-3168. [CrossRef]

198. Bland, B.H.; Oddie, S.D.; Colom, L.V. Mechanisms of neural synchrony in the septohippocampal pathways underlying hippocampal theta generation. J. Neurosci. 1999, 19, 3223-3237. [CrossRef]

199. Cataldi, M.; Vigliotti, C. The evolving concept of the intrinsic hippocampal theta/gamma oscillator. Front. Biosci. 2018, 10, 143-165. [CrossRef]

200. Li, S.; Topchiy, I.; Kocsis, B. The effect of atropine administered in the medial septum or hippocampus on high-and low-frequency theta rhythms in the hippocampus of urethane anesthetized rats. Synapse 2007, 61, 412-419. [CrossRef]

201. Fornari, R.V.; Moreira, K.M.; Oliveira, M.G. Effects of the selective M1 muscarinic receptor antagonist dicyclomine on emotional memory. Learn. Mem. 2000, 7, 287-292. [CrossRef] [PubMed]

202. Rossi, M.A.; Mash, D.C.; de Toledo-Morrell, L. Spatial memory in aged rats is related to PKC $\gamma$-dependent G-protein coupling of the M1 receptor. Neurobiol. Aging 2005, 26, 53-68. [CrossRef] [PubMed]

203. Patricio, R.R.; Soares, J.C.; Oliveira, M.G. M1 muscarinic receptors are necessary for retrieval of remote context fear memory. Physiol. Behav. 2017, 169, 202-207. [CrossRef] [PubMed]

204. Carey, G.J.; Billard, W.; Binch, H., III; Cohen-Williams, M.; Crosby, G.; Grzelak, M.; Guzik, H.; Kozlowski, J.A.; Lowe, D.B.; Pond, A.J.; et al. SCH 57790, a selective muscarinic M2 receptor antagonist, releases acetylcholine and produces cognitive enhancement in laboratory animals. Eur. J. Pharmacol. 2001, 431, 189-200. [CrossRef]

205. Rowe, W.B.; O’Donnell, J.P.; Pearson, D.; Rose, G.M.; Meaney, M.J.; Quirion, R. Long-term effects of BIBN-99, a selective muscarinic $\mathrm{M} 2$ receptor antagonist, on improving spatial memory performance in aged cognitively impaired rats. Behav. Brain Res. 2003, 145, 171-178. [CrossRef]

206. Bainbridge, N.K.; Koselke, L.R.; Jeon, J.; Bailey, K.R.; Wess, J.; Crawley, J.N.; Wrenn, C.C. Learning and memory impairments in a congenic C57BL/6 strain of mice that lacks the M2 muscarinic acetylcholine receptor subtype. Behav. Brain Res. 2008, 190, 50-58. [CrossRef] [PubMed]

207. Poulin, B.; Butcher, A.; McWilliams, P.; Bourgognon, J.M.; Pawlak, R.; Kong, K.C.; Bottrill, A.; Mistry, S.; Wess, J.; Rosethorne, E.M.; et al. The M3-muscarinic receptor regulates learning and memory in a receptor phosphorylation/arrestin-dependent manner. Proc. Natl. Acad. Sci. USA 2010, 107, 9440-9445. [CrossRef]

208. Ferreira, A.R.; Fürstenau, L.; Blanco, C.; Kornisiuk, E.; Sánchez, G.; Daroit, D.; e Silva, M.C.; Cerveñansky, C.; Jerusalinsky, D.; Quillfeldt, J.A. Role of hippocampal M1 and M4 muscarinic receptor subtypes in memory consolidation in the rat. Pharmacol. Biochem. Behav. 2003, 74, 411-415. [CrossRef]

209. Mulugeta, E.; Karlsson, E.; Islam, A.; Kalaria, R.; Mangat, H.; Winblad, B.; Adem, A. Loss of muscarinic M4 receptors in hippocampus of Alzheimer patients. Brain Res. 2003, 960, 259-262. [CrossRef]

210. Foster, D.J.; Choi, D.L.; Conn, P.J.; Rook, J.M. Activation of M1 and M4 muscarinic receptors as potential treatments for Alzheimer's disease and schizophrenia. Neuropsych. Dis. Treat. 2014, 10, 183-191.

211. Dannenberg, H.; Young, K.; Hasselmo, M. Modulation of hippocampal circuits by muscarinic and nicotinic receptors. Front. Neural Circuit. 2017, 11, 102. [CrossRef] [PubMed]

212. Teles-Grilo Ruivo, L.; Mellor, J. Cholinergic modulation of hippocampal network function. Front. Synaptic Neurosci. 2013, 5, 2. [CrossRef] [PubMed]

213. Leaderbrand, K.; Chen, H.J.; Corcoran, K.A.; Guedea, A.L.; Jovasevic, V.; Wess, J.; Radulovic, J. Muscarinic acetylcholine receptors act in synergy to facilitate learning and memory. Learn. Mem. 2016, 23, 631-638. [CrossRef] [PubMed] 
214. Shinoe, T.; Matsui, M.; Taketo, M.M.; Manabe, T. Modulation of synaptic plasticity by physiological activation of M1 muscarinic acetylcholine receptors in the mouse hippocampus. J. Neurosci. 2005, 25, 11194-11200. [CrossRef] [PubMed]

215. Buchanan, K.A.; Petrovic, M.M.; Chamberlain, S.E.; Marrion, N.V.; Mellor, J.R. Facilitation of long-term potentiation by muscarinic M1 receptors is mediated by inhibition of SK channels. Neuron 2010, 68, 948-963. [CrossRef]

216. Dennis, S.H.; Pasqui, F.; Colvin, E.M.; Sanger, H.; Mogg, A.J.; Felder, C.C.; Broad, L.M.; Fitzjohn, S.M.; Isaac, J.T.; Mellor, J.R. Activation of muscarinic M1 acetylcholine receptors induces long-term potentiation in the hippocampus. Cereb. Cortex 2015, 26, 414-426. [CrossRef]

217. Anisuzzaman, A.S.; Uwada, J.; Masuoka, T.; Yoshiki, H.; Nishio, M.; Ikegaya, Y.; Takahashi, N.; Matsuki, N.; Fujibayashi, Y.; Yonekura, Y.; et al. Novel contribution of cell surface and intracellular M1-muscarinic acetylcholine receptors to synaptic plasticity in hippocampus. J. Neurochem. 2013, 126, 360-371. [CrossRef]

218. Ovsepian, S.V.; Anwyl, R.; Rowan, M.J. Endogenous acetylcholine lowers the threshold for long-term potentiation induction in the CA1 area through muscarinic receptor activation: In vivo study. Eur. J. Neurosci. 2004, 20, 1267-1275. [CrossRef]

219. Le Duigou, C.; Savary, E.; Kullmann, D.M.; Miles, R. Induction of anti-Hebbian LTP in CA1 stratum oriens interneurons: Interactions between group I metabotropic glutamate receptors and M1 muscarinic receptors. J. Neurosci. 2015, 35, 13542-13554. [CrossRef]

220. Kamsler, A.; McHugh, T.J.; Gerber, D.; Huang, S.Y.; Tonegawa, S. Presynaptic m1 muscarinic receptors are necessary for mGluR long-term depression in the hippocampus. Proc. Natl. Acad. Sci. USA 2010, 107, 1618-1623. [CrossRef]

221. Dickinson, B.A.; Jo, J.; Seok, H.; Son, G.H.; Whitcomb, D.J.; Davies, C.H.; Sheng, M.; Collingridge, G.L.; Cho, K. A novel mechanism of hippocampal LTD involving muscarinic receptor-triggered interactions between AMPARs, GRIP and liprin- $\alpha$. Mol. Brain 2009, 2, 18. [CrossRef] [PubMed]

222. Jo, J.; Son, G.H.; Winters, B.L.; Kim, M.J.; Whitcomb, D.J.; Dickinson, B.A.; Lee, Y.B.; Futai, K.; Amici, M.; Sheng, M.; et al. Muscarinic receptors induce LTD of NMDAR EPSCs via a mechanism involving hippocalcin, AP2 and PSD-95. Nat. Neurosci. 2010, 13, 1216-1224. [CrossRef] [PubMed]

223. Luo, L.; Chen, W.H.; Wang, M.; Zhu, D.M.; She, J.Q.; Ruan, D.Y. Modulation of long-term potentiation by individual subtypes of muscarinic acetylcholine receptor in the rat dentate gyrus. Hippocampus 2008, 18, 989-995. [CrossRef] [PubMed]

224. Prokopova, I. Noradrenaline and behavior. Cesk Fysiol. 2010, 59, 51-58.

225. Borodovitsyna, O.; Flamini, M.; Chandler, D. Noradrenergic modulation of cognition in health and disease. Neural Plast. 2017, 2017, 6031478. [CrossRef] [PubMed]

226. Gibbs, M.E.; Hutchinson, D.S.; Summers, R.J. Noradrenaline release in the locus coeruleus modulates memory formation and consolidation; roles for $\alpha$-and $\beta$-adrenergic receptors. Neuroscience 2010, 170, 1209-1222. [CrossRef] [PubMed]

227. Kukolja, J.; Klingmüller, D.; Maier, W.; Fink, G.R.; Hurlemann, R. Noradrenergic-glucocorticoid modulation of emotional memory encoding in the human hippocampus. Psychol. Med. 2011, 41, 2167-2176. [CrossRef]

228. Gazarini, L.; Stern, C.A.; Carobrez, A.P.; Bertoglio, L.J. Enhanced noradrenergic activity potentiates fear memory consolidation and reconsolidation by differentially recruiting $\alpha 1$-and $\beta$-adrenergic receptors. Learn. Mem. 2013, 20, 210-219. [CrossRef]

229. Coradazzi, M.; Gulino, R.; Fieramosca, F.; Falzacappa, L.V.; Riggi, M.; Leanza, G. Selective noradrenaline depletion impairs working memory and hippocampal neurogenesis. Neurobiol. Aging 2016, 48, 93-102. [CrossRef]

230. Conversi, D.; Cruciani, F.; Accoto, A.; Cabib, S. Positive emotional arousal increases duration of memory traces: Different role of dopamine D1 receptor and $\beta$-adrenoceptor activation. Pharmacol. Biochem. Behav. 2014, 122, 158-163. [CrossRef]

231. Sara, S.J. Locus coeruleus in time with the making of memories. Curr. Opin. Neurobiol. 2015, 35, 87-94. [CrossRef] [PubMed]

232. Atzori, M.; Cuevas-Olguin, R.; Esquivel-Rendon, E.; Garcia-Oscos, F.; Salgado-Delgado, R.C.; Saderi, N.; Miranda-Morales, M.; Treviño, M.; Pineda, J.C.; Salgado, H. Locus ceruleus norepinephrine release: A central regulator of CNS spatio-temporal activation? Front. Synaptic Neurosci. 2016, 8, 25. [CrossRef] [PubMed] 
233. Puumala, T.; Greijus, S.; Narinen, K.; Haapalinna, A.; Riekkinen Sr, P.; Sirviö, J. Stimulation of alpha-1 adrenergic receptors facilitates spatial learning in rats. Eur. Neuropsychopharmacol. 1998, 8, 17-26. [CrossRef]

234. Doze, V.A.; Papay, R.S.; Goldenstein, B.L.; Gupta, M.K.; Collette, K.M.; Nelson, B.W.; Lyons, M.J.; Davis, B.A.; Luger, E.J.; Wood, S.G.; et al. Long-term $\alpha 1$ A-adrenergic receptor stimulation improves synaptic plasticity, cognitive function, mood, and longevity. Mol. Pharmacol. 2011, 80, 747-758. [CrossRef]

235. Petrasek, T.; Doulames, V.; Prokopova, I.; Vales, K.; Stuchlik, A. Combined administration of alpha1-adrenoceptor antagonist prazosin and beta-blocker propranolol impairs spatial avoidance learning on a dry arena. Behav. Brain Res. 2010, 208, 402-407. [CrossRef]

236. Haggerty, D.C.; Glykos, V.; Adams, N.E.; LeBeau, F.E. Bidirectional modulation of hippocampal gamma $(20-80 \mathrm{~Hz})$ frequency activity in vitro via alpha $(\alpha)$-and beta $(\beta)$-adrenergic receptors (AR). Neuroscience 2013, 253, 142-154. [CrossRef]

237. Lazzaro, S.C.; Hou, M.; Cunha, C.; LeDoux, J.E.; Cain, C.K. Antagonism of lateral amygdala alpha1-adrenergic receptors facilitates fear conditioning and long-term potentiation. Learn. Mem. 2010, 17, 489-493. [CrossRef]

238. Kim, C.H.; Ko, I.G.; Kim, S.E.; Shin, M.S.; Kang, Y.H.; Cho, J.W.; Shin, K.M.; Kim, C.J.; Lim, B.V.; Kim, K.H. Alpha1-adrenoceptor antagonists improve memory by activating N-methyl-D-aspartate-induced ion currents in the rat hippocampus. Int. Neurourol. J. 2015, 19, 228-236. [CrossRef]

239. Scheiderer, C.L.; Dobrunz, L.E.; McMahon, L.L. Novel form of long-term synaptic depression in rat hippocampus induced by activation of $\alpha 1$ adrenergic receptors. J. Neurophysiol. 2004, 91, 1071-1077. [CrossRef]

240. Li, C.J.; Zhou, M.; Li, H.G.; Lv, Q.; Xu, X.L.; Guo, L.J. Clonidine suppresses the induction of long-term potentiation by inhibiting HCN channels at the Schaffer collateral-CA1 synapse in anesthetized adult rats. Cell. Mol. Neurobiol. 2013, 33, 1075-1086. [CrossRef]

241. Lim, E.P.; Dawe, G.S.; Jay, T.M. Activation of beta-and alpha-2-adrenoceptors in the basolateral amygdala has opposing effects on hippocampal-prefrontal long-term potentiation. Neurobiol. Learn. Mem. 2017, 137, 163-170. [CrossRef] [PubMed]

242. Papaleonidopoulos, V.; Papatheodoropoulos, C. $\beta$-adrenergic receptors reduce the threshold for induction and stabilization of LTP and enhance its magnitude via multiple mechanisms in the ventral but not the dorsal hippocampus. Neurobiol. Learn. Mem. 2018, 151, 71-84. [CrossRef] [PubMed]

243. Jenson, D.; Yang, K.; Acevedo-Rodriguez, A.; Levine, A.; Broussard, J.I.; Tang, J.; Dani, J.A. Dopamine and norepinephrine receptors participate in methylphenidate enhancement of in vivo hippocampal synaptic plasticity. Neuropharmacology 2015, 90, 23-32. [CrossRef] [PubMed]

244. Connor, S.A.; Maity, S.; Roy, B.; Ali, D.W.; Nguyen, P.V. Conversion of short-term potentiation to long-term potentiation in mouse CA1 by coactivation of $\beta$-adrenergic and muscarinic receptors. Learn. Mem. 2012, 19, 535-542. [CrossRef] [PubMed]

245. Qian, H.; Matt, L.; Zhang, M.; Nguyen, M.; Patriarchi, T.; Koval, O.M.; Anderson, M.E.; He, K.; Lee, H.K.; Hell, J.W. $\beta 2$-Adrenergic receptor supports prolonged theta tetanus-induced LTP. J. Neurophysiol. 2012, 107, 2703-2712. [CrossRef]

246. Zhou, H.C.; Sun, Y.Y.; Cai, W.; He, X.T.; Yi, F.; Li, B.M.; Zhang, X.H. Activation of $\beta 2$-adrenoceptor enhances synaptic potentiation and behavioral memory via cAMP-PKA signaling in the medial prefrontal cortex of rats. Learn. Mem. 2013, 20, 274-284. [CrossRef]

247. Havekes, R.; Canton, D.A.; Park, A.J.; Huang, T.; Nie, T.; Day, J.P.; Guercio, L.A.; Grimes, Q.; Luczak, V.; Gelman, I.H.; et al. Gravin orchestrates protein kinase A and $\beta 2$-adrenergic receptor signaling critical for synaptic plasticity and memory. J. Neurosci. 2012, 32, 18137-18149. [CrossRef]

248. Chay, A.; Zamparo, I.; Koschinski, A.; Zaccolo, M.; Blackwell, K.T. Control of $\beta$ AR-and N-methyl-D-aspartate (NMDA) receptor-dependent cAMP dynamics in hippocampal neurons. PLoS Comput. Biol. 2016, 12, e1004735. [CrossRef]

249. Qian, H.; Patriarchi, T.; Price, J.L.; Matt, L.; Lee, B.; Nieves-Cintrón, M.; Buonarati, O.R.; Chowdhury, D.; Nanou, E.; Nystoriak, M.A.; et al. Phosphorylation of Ser1928 mediates the enhanced activity of the L-type $\mathrm{Ca}^{2+}$ channel Cav1. 2 by the $\beta 2$-adrenergic receptor in neurons. Sci. Signal. 2017, 10, eaaf9659. [CrossRef]

250. Liu, Y.; Cui, L.; Schwarz, M.K.; Dong, Y.; Schlüter, O.M. Adrenergic gate release for spike timing-dependent synaptic potentiation. Neuron 2017, 93, 394-408. [CrossRef]

251. Barnes, N.M.; Sharp, T. A review of central 5-HT receptors and their function. Neuropharmacology 1999, 38, 1083-1152. [CrossRef] 
252. Nichols, D.E.; Nichols, C.D. Serotonin receptors. Chem. Rev. 2008, 108, 1614-1641. [CrossRef] [PubMed]

253. Fernandez, S.P.; Muzerelle, A.; Scotto-Lomassese, S.; Barik, J.; Gruart, A.; Delgado-García, J.M.; Gaspar, P. Constitutive and acquired serotonin deficiency alters memory and hippocampal synaptic plasticity. Neuropsychopharmacology 2017, 42, 512-523. [CrossRef] [PubMed]

254. Baratta, M.V.; Kodandaramaiah, S.B.; Monahan, P.E.; Yao, J.; Weber, M.D.; Lin, P.A.; Gisabella, B.; Petrossian, N.; Amat, J.; Kim, K.; et al. Stress enables reinforcement-elicited serotonergic consolidation of fear memory. Biol. Psychiat. 2016, 79, 814-822. [CrossRef]

255. Darcet, F.; Gardier, A.M.; David, D.J.; Guilloux, J.P. Chronic 5-HT4 receptor agonist treatment restores learning and memory deficits in a neuroendocrine mouse model of anxiety/depression. Neurosci. Lett. 2016, 616, 197-203. [CrossRef]

256. Lo, A.C.; De Maeyer, J.H.; Vermaercke, B.; Callaerts-Vegh, Z.; Schuurkes, J.A.; D'Hooge, R. SSP-002392, a new 5-HT4 receptor agonist, dose-dependently reverses scopolamine-induced learning and memory impairments in C57Bl/6 mice. Neuropharmacology 2014, 85, 178-189. [CrossRef]

257. Quiedeville, A.; Boulouard, M.; Hamidouche, K.; Costa-Aze, V.D.; Nee, G.; Rochais, C.; Dallemagne, P.; Fabis, F.; Freret, T.; Bouet, V. Chronic activation of 5-HT4 receptors or blockade of 5-HT6 receptors improve memory performances. Behav. Brain Res. 2015, 293, 10-17. [CrossRef]

258. Zareifopoulos, N.; Papatheodoropoulos, C. Effects of 5-HT-7 receptor ligands on memory and cognition. Neurobiol. Learn. Mem. 2016, 136, 204-209. [CrossRef]

259. Chen, A.; Hough, C.J.; Li, H. Serotonin type II receptor activation facilitates synaptic plasticity via $\mathrm{N}$-methyl-D-aspartate-mediated mechanism in the rat basolateral amygdala. Neuroscience 2003, 119, $53-63$. [CrossRef]

260. Barre, A.; Berthoux, C.; De Bundel, D.; Valjent, E.; Bockaert, J.; Marin, P.; Bécamel, C. Presynaptic serotonin 2A receptors modulate thalamocortical plasticity and associative learning. Proc. Natl. Acad. Sci. USA 2016, 113, E1382-E1391. [CrossRef]

261. Burattini, C.; Battistini, G.; Tamagnini, F.; Aicardi, G. Low-frequency stimulation evokes serotonin release in the nucleus accumbens and induces long-term depression via production of endocannabinoid. J. Neurophysiol. 2013, 111, 1046-1055. [CrossRef] [PubMed]

262. Zhong, P.; Liu, W.; Gu, Z.; Yan, Z. Serotonin facilitates long-term depression induction in prefrontal cortex via p38 MAPK/Rab5-mediated enhancement of AMPA receptor internalization. J. Physiol. 2008, 586, 4465-4479. [CrossRef] [PubMed]

263. Ciranna, Á. Serotonin as a modulator of glutamate-and GABA-mediated neurotransmission: Implications in physiological functions and in pathology. Curr. Neuropharmacol. 2006, 4, 101-114. [CrossRef] [PubMed]

264. Pirttimaki, T.M.; Sims, R.E.; Saunders, G.; Antonio, S.A.; Codadu, N.K.; Parri, H.R. Astrocyte-mediated neuronal synchronization properties revealed by false gliotransmitter release. J. Neurosci. 2017, 37, 9859-9870. [CrossRef] [PubMed]

265. Sims, R.E.; Butcher, J.B.; Parri, H.R.; Glazewski, S. Astrocyte and neuronal plasticity in the somatosensory system. Neural Plast. 2015, 2015, 732014. [CrossRef]

266. Holtzclaw, L.A.; Pandhit, S.; Bare, D.J.; Mignery, G.A.; Russell, J.T. Astrocytes in adult rat brain express type 2 inositol 1, 4, 5-trisphosphate receptors. Glia 2002, 39, 69-84. [CrossRef]

267. Newman, E.A. New roles for astrocytes: Regulation of synaptic transmission. Trends Neurosci. 2003, 26, 536-542. [CrossRef]

268. Verkhratsky, A. Neurotransmitter receptors in astrocytes. In Astrocytes in (Patho) Physiology of the Nervous System, 1st ed.; Parpura, V., Haydon, P.G., Eds.; Springer: Boston, MA, USA, 2009; pp. 49-67.

269. Brockett, A.T.; Kane, G.A.; Monari, P.K.; Briones, B.A.; Vigneron, P.A.; Barber, G.A.; Bermudez, A.; Dieffenbach, U.; Kloth, A.D.; Buschman, T.J.; et al. Evidence supporting a role for astrocytes in the regulation of cognitive flexibility and neuronal oscillations through the Ca2+ binding protein S100ß. PLoS ONE 2018, 13, e0195726. [CrossRef]

270. Pabst, M.; Braganza, O.; Dannenberg, H.; Hu, W.; Pothmann, L.; Rosen, J.; Mody, I.; van Loo, K.; Deisseroth, K.; Becker, A.J.; et al. Astrocyte intermediaries of septal cholinergic modulation in the hippocampus. Neuron 2016, 90, 853-865. [CrossRef]

271. Paukert, M.; Agarwal, A.; Cha, J.; Doze, V.A.; Kang, J.U.; Bergles, D.E. Norepinephrine controls astroglial responsiveness to local circuit activity. Neuron 2014, 82, 1263-1270. [CrossRef] 
272. Bekar, L.K.; He, W.; Nedergaard, M. Locus coeruleus $\alpha$-adrenergic-mediated activation of cortical astrocytes in vivo. Cereb. Cortex 2008, 18, 2789-2795. [CrossRef] [PubMed]

273. Navarrete, M.; Perea, G.; de Sevilla, D.F.; Gómez-Gonzalo, M.; Núñez, A.; Martín, E.D.; Araque, A. Astrocytes mediate in vivo cholinergic-induced synaptic plasticity. PLoS Boil. 2012, 10, e1001259. [CrossRef] [PubMed]

274. Takata, N.; Mishima, T.; Hisatsune, C.; Nagai, T.; Ebisui, E.; Mikoshiba, K.; Hirase, H. Astrocyte calcium signaling transforms cholinergic modulation to cortical plasticity in vivo. J. Neurosci. 2011, 31, 18155-18165. [CrossRef] [PubMed]

275. Pankratov, Y.; Lalo, U. Role for astroglial $\alpha 1$-adrenoreceptors in gliotransmission and control of synaptic plasticity in the neocortex. Front. Cell. Neurosci. 2015, 9, 230. [CrossRef]

276. Gao, V.; Suzuki, A.; Magistretti, P.J.; Lengacher, S.; Pollonini, G.; Steinman, M.Q.; Alberini, C.M. Astrocytic $\beta 2$-adrenergic receptors mediate hippocampal long-term memory consolidation. Proc. Natl. Acad. Sci. USA 2016, 113, 8526-8531. [CrossRef]

277. Jensen, C.J.; Demol, F.; Bauwens, R.; Kooijman, R.; Massie, A.; Villers, A.; Ris, L.; De Keyser, J. Astrocytic $\beta 2$ adrenergic receptor gene deletion affects memory in aged mice. PLoS ONE 2016, 11, e0164721. [CrossRef]

278. Petrelli, F.; Dallérac, G.; Pucci, L.; Calì, C.; Zehnder, T.; Sultan, S.; Lecca, S.; Chicca, A.; Ivanov, A.; Asensio, C.S.; et al. Dysfunction of homeostatic control of dopamine by astrocytes in the developing prefrontal cortex leads to cognitive impairments. Mol. Psychiat. 2018. [CrossRef]

279. Navarrete, M.; Cuartero, M.I.; Palenzuela, R.; Draffin, J.E.; Konomi, A.; Serra, I.; Colié, S.; Castaño-Castaño, S.; Hasan, M.T.; Nebreda, Á.R.; et al. Astrocytic p38 $\alpha$ MAPK drives NMDA receptor-dependent long-term depression and modulates long-term memory. Nat. Commun. 2019, 10, 2968. [CrossRef]

280. Zhu, J.J.; Qin, Y.; Zhao, M.; Van Aelst, L.; Malinow, R. Ras and Rap control AMPA receptor trafficking during synaptic plasticity. Cell 2002, 110, 443-455. [CrossRef]

281. Izumi, Y.; Zorumski, C.F. NMDA receptors, mGluR5, and endocannabinoids are involved in a cascade leading to hippocampal long-term depression. Neuropsychopharmacology 2012, 37, 609-617. [CrossRef]

282. Nevian, T.; Sakmann, B. Spine $\mathrm{Ca}^{2+}$ signaling in spike-timing-dependent plasticity. J. Neurosci. 2006, 26, 11001-11013. [CrossRef] [PubMed]

283. Andrade-Talavera, Y.; Duque-Feria, P.; Paulsen, O.; Rodríguez-Moreno, A. Presynaptic spike timing-dependent long-term depression in the mouse hippocampus. Cereb. Cortex 2016, 26, 3637-3654. [CrossRef] [PubMed]

284. Min, R.; Nevian, T. Astrocyte signaling controls spike timing-dependent depression at neocortical synapses. Nat. Neurosci. 2012, 15, 746-753. [CrossRef] [PubMed]

285. Paulsen, O.; Sejnowski, T.J. Natural patterns of activity and long-term synaptic plasticity. Curr. Opin. Neurobiol. 2000, 10, 172-180. [CrossRef]

286. Zarnadze, S.; Bäuerle, P.; Santos-Torres, J.; Böhm, C.; Schmitz, D.; Geiger, J.R.; Dugladze, T.; Gloveli, T. Cell-specific synaptic plasticity induced by network oscillations. E-Life 2016, 5, e14912. [CrossRef] [PubMed]

287. Masquelier, T.; Hugues, E.; Deco, G.; Thorpe, S.J. Oscillations, phase-of-firing coding, and spike timing-dependent plasticity: An efficient learning scheme. J. Neurosci. 2009, 29, 13484-13493. [CrossRef]

288. Hanslmayr, S.; Staresina, B.P.; Bowman, H. Oscillations and episodic memory: Addressing the synchronization/desynchronization conundrum. Trends Neurosci. 2016, 39, 16-25. [CrossRef]

289. Timofeev, I.; Bazhenov, M.; Seigneur, J.; Sejnowski, T. Neuronal synchronization and thalamocortical rhythms in sleep, wake and epilepsy. In Jasper's Basic Mechanisms of the Epilepsies [Internet], 4th ed.; Noebels, J., Avoli, M., Rogawski, M., Olsen, R., Delgado-Escueta, A., Eds.; National Center for Biotechnology Information: Bethesda, MD, USA, 2012; pp. 217-245.

290. Nadim, F.; Bucher, D. Neuromodulation of neurons and synapses. Curr. Opin. Neurobiol. 2014, 29 , 48-56. [CrossRef]

291. Pawlak, V.; Wickens, J.R.; Kirkwood, A.; Kerr, J.N. Timing is not everything: Neuromodulation opens the STDP gate. Front. Synaptic Neurosci. 2010, 2, 146. [CrossRef]

292. Foncelle, A.; Mendes, A.; Jedrzejewska-Szmek, J.; Valtcheva, S.; Berry, H.; Blackwell, K.T.; Venance, L. Modulation of spike-timing dependent plasticity: Towards the inclusion of a third factor in computational models. Front. Comput. Neurosci. 2018, 12, 49. [CrossRef]

293. Park, A.J.; Abel, T. PKA Anchoring and Synaptic Tagging and Capture. In Synaptic Tagging and Capture, 1st ed.; Sajikumar, S., Ed.; Springer: New York, NY, USA, 2015; pp. 61-78. 
294. Asok, A.; Leroy, F.; Rayman, J.B.; Kandel, E.R. Molecular mechanisms of the memory trace. Trends Neurosci. 2018, 42, 14-22. [CrossRef] [PubMed]

295. Maity, S.; Jarome, T.J.; Blair, J.; Lubin, F.D.; Nguyen, P.V. Noradrenaline goes nuclear: Epigenetic modifications during long-lasting synaptic potentiation triggered by activation of $\beta$-adrenergic receptors. J. Physiol. 2016, 594, 863-881. [CrossRef] [PubMed]

296. Dayan, P.; Yu, A.J. Phasic norepinephrine: A neural interrupt signal for unexpected events. Netw. Comput. Neural Syst. 2006, 17, 335-350. [CrossRef] [PubMed]

297. Devilbiss, D.M.; Waterhouse, B.D. Phasic and tonic patterns of locus coeruleus output differentially modulate sensory network function in the awake rat. J. Neurophysiol. 2010, 105, 69-87. [CrossRef]

298. Howells, F.M.; Stein, D.J.; Russell, V.A. Synergistic tonic and phasic activity of the locus coeruleus norepinephrine (LC-NE) arousal system is required for optimal attentional performance. Metab. Brain Dis. 2012, 27, 267-274. [CrossRef]

299. Sarter, M.; Parikh, V.; Howe, W.M. Phasic acetylcholine release and the volume transmission hypothesis: Time to move on. Nat. Rev. Neurosci. 2009, 10, 383-390. [CrossRef]

300. Mattinson, C.E.; Burmeister, J.J.; Quintero, J.E.; Pomerleau, F.; Huettl, P.; Gerhardt, G.A. Tonic and phasic release of glutamate and acetylcholine neurotransmission in sub-regions of the rat prefrontal cortex using enzyme-based microelectrode arrays. J. Neurosci. Meth. 2011, 202, 199-208. [CrossRef]

301. Ruivo, L.M.; Baker, K.L.; Conway, M.W.; Kinsley, P.J.; Gilmour, G.; Phillips, K.G.; Isaac, J.T.; Lowry, J.P.; Mellor, J.R. Coordinated acetylcholine release in prefrontal cortex and hippocampus is associated with arousal and reward on distinct timescales. Cell Rep. 2017, 18, 905-917. [CrossRef]

302. Hall, I.C.; Rebec, G.V.; Hurley, L.M. Serotonin in the inferior colliculus fluctuates with behavioral state and environmental stimuli. J. Exp. Biol. 2010, 213, 1009-1017. [CrossRef]

303. Cohen, J.Y.; Amoroso, M.W.; Uchida, N. Serotonergic neurons signal reward and punishment on multiple timescales. E-Life 2015, 4, e06346. [CrossRef]

304. Grace, A.A.; Floresco, S.B.; Goto, Y.; Lodge, D.J. Regulation of firing of dopaminergic neurons and control of goal-directed behaviors. Trends Neurosci. 2007, 30, 220-227. [CrossRef] [PubMed]

305. Lodge, D.J.; Grace, A.A. The hippocampus modulates dopamine neuron responsivity by regulating the intensity of phasic neuron activation. Neuropsychopharmacology 2006, 31, 1356-1361. [CrossRef] [PubMed]

306. Dreyer, J.K.; Herrik, K.F.; Berg, R.W.; Hounsgaard, J.D. Influence of phasic and tonic dopamine release on receptor activation. J. Neurosci. 2010, 30, 14273-14283. [CrossRef] [PubMed]

307. Otani, S.; Bai, J.; Blot, K. Dopaminergic modulation of synaptic plasticity in rat prefrontal neurons. Neurosci. Bull. 2015, 31, 183-190. [CrossRef] [PubMed]

308. Cools, R.; D’Esposito, M. Inverted-U-shaped dopamine actions on human working memory and cognitive control. Biol. Psychiat. 2011, 69, e113-e125. [CrossRef]

309. Smucny, J.; Olincy, A.; Eichman, L.S.; Tregellas, J.R. Neuronal effects of nicotine during auditory selective attention. Psychopharmacology 2015, 232, 2017-2028. [CrossRef]

310. Cano-Colino, M.; Almeida, R.; Gomez-Cabrero, D.; Artigas, F.; Compte, A. Serotonin regulates performance nonmonotonically in a spatial working memory network. Cereb. Cortex 2013, 24, 2449-2463. [CrossRef]

311. Devilbiss, D.M. Consequences of tuning network function by tonic and phasic locus coeruleus output and stress: Regulating detection and discrimination of peripheral stimuli. Brain Res. 2019, 1709, 16-27. [CrossRef]

312. Thiele, A.; Bellgrove, M.A. Neuromodulation of attention. Neuron 2018, 97, 769-785. [CrossRef]

313. Avery, M.C.; Krichmar, J.L. Neuromodulatory systems and their interactions: A review of models, theories, and experiments. Front. Neural Circuit. 2017, 11, 108. [CrossRef]

314. Shen, W.; Plotkin, J.L.; Francardo, V.; Ko, W.K.; Xie, Z.; Li, Q.; Fieblinger, T.; Wess, J.; Neubig, R.R.; Lindsley, C.W.; et al. M4 muscarinic receptor signaling ameliorates striatal plasticity deficits in models of L-DOPA-induced dyskinesia. Neuron 2015, 88, 762-773. [CrossRef] [PubMed]

315. Xu, Z.H.; Yang, Q.; Feng, B.; Liu, S.B.; Zhang, N.; Xing, J.H.; Li, X.Q.; Wu, Y.M.; Gao, G.D.; Zhao, M.G. Group I mGluR antagonist rescues the deficit of D1-induced LTP in a mouse model of fragile X syndrome. Mol. Neurodegener. 2012, 7, 24. [CrossRef] [PubMed]

316. Huang, C.S.; Shi, S.H.; Ule, J.; Ruggiu, M.; Barker, L.A.; Darnell, R.B.; Jan, Y.N.; Jan, L.Y. Common molecular pathways mediate long-term potentiation of synaptic excitation and slow synaptic inhibition. Cell 2005, 123, 105-118. [CrossRef] [PubMed] 
317. Sánchez-Rodríguez, I.; Gruart, A.; Delgado-García, J.M.; Jiménez-Díaz, L.; Navarro-López, J.D. Role of GirK Channels in Long-Term Potentiation of Synaptic Inhibition in an In Vivo Mouse Model of Early Amyloid- $\beta$ Pathology. Int. J. Mol. Sci. 2019, 20, 1168. [CrossRef] [PubMed]

318. Lüscher, C.; Slesinger, P.A. Emerging roles for $G$ protein-gated inwardly rectifying potassium (GIRK) channels in health and disease. Nat. Rev. Neurosci. 2010, 11, 301-315. [CrossRef] [PubMed]

319. Jena, P.K.; Sheng, L.; Di Lucente, J.; Jin, L.W.; Maezawa, I.; Wan, Y.J. Dysregulated bile acid synthesis and dysbiosis are implicated in Western diet-induced systemic inflammation, microglial activation, and reduced neuroplasticity. FASEB J. 2018, 32, 2866-2877. [CrossRef]

320. Bazzari, F.H.; Abdallah, D.M.; El-Abhar, H.S. Chenodeoxycholic Acid Ameliorates AlCl3-Induced Alzheimer's Disease Neurotoxicity and Cognitive Deterioration via Enhanced Insulin Signaling in Rats. Molecules 2019, 24, 1992. [CrossRef]

321. Jha, S.K.; Jha, N.K.; Kumar, D.; Sharma, R.; Shrivastava, A.; Ambasta, R.K.; Kumar, P. Stress-induced synaptic dysfunction and neurotransmitter release in Alzheimer's disease: Can neurotransmitters and neuromodulators be potential therapeutic targets? J. Alzheimers Dis. 2017, 57, 1017-1039. [CrossRef]

322. Bazzari, F.H.; Abdallah, D.M.; El-Abhar, H.S. Pharmacological Interventions to Attenuate Alzheimer's Disease Progression: The Story So Far. Curr. Alzheimer Res. 2019, 16, 261-277. [CrossRef]

(C) 2019 by the authors. Licensee MDPI, Basel, Switzerland. This article is an open access article distributed under the terms and conditions of the Creative Commons Attribution (CC BY) license (http://creativecommons.org/licenses/by/4.0/). 